\title{
Systematic review of health state utility values in metastatic non-small cell lung cancer with a focus on previously treated patients
}

Noman Paracha ${ }^{1 *}$, Ahmed Abdulla ${ }^{1,3}$ and Katherine S. MacGilchrist ${ }^{2}$

\begin{abstract}
Background: Health state utility values (HSUVs) are an important input to economic evaluations and the choice of HSUV can affect the estimate of relative cost-effectiveness between interventions. This systematic review identified utility scores for patients with metastatic non-small cell lung cancer (mNSCLC), as well as disutilities or utility decrements relevant to the experience of patients with mNSCLC, by treatment line and health state.

Methods: The MEDLINE ${ }^{\oplus}$ Embase and Cochrane Library databases were systematically searched (September 2016) for publications describing HSUVs in mNSCLC in any treatment line. The EQ-5D website, the School of Health and Related Research Health Utilities Database (SCHARRHUD) and major pharmacoeconomic and clinical conferences in 2015-2016 were also queried. Studies in adults with previously treated mNSCLC were selected for further analysis. The information extracted included study design, description of treatment and health state, respondent details, instrument and tariff, HSUV or (dis) utility decrement estimates, quality of study, and appropriateness for use in economic evaluations.
\end{abstract}

Results: Of 1883 references identified, 36 publications of 34 studies were included: 19 reported EQ-5D scores; eight reported HSUVs from valuations of vignettes made by members of the public using standard gamble (SG) or time trade-off (TTO); two reported SG or TTO directly elicited from patients; two reported EQ-5D visual analogue scale scores only; one reported Assessment of Quality of Life instrument scores; one reported HSUVs for caregivers to patients with mNSCLC using the 12-item Short-Form Health Survey; and one estimated HSUVs based on expert opinion. The range of HSUVs identified for comparable health states showed how differences in study type, tariff, health state and the measures used can drive variation in HSUV estimates.

Conclusions: This systematic review provides a set of published HSUVS that are relevant to the experience of adult patients previously treated for mNSCLC. Our review begins to address the challenge of identifying reliable estimates of utility values in mNSCLC that are suitable for use in economic evaluations, and also highlights how varying estimates result from differences in methodology.

Keywords: Health state utility values (HSUVs), Health-related quality of life (HRQoL), Metastatic non-small cell lung cancer (mNSCLC), Multi-attribute utility instruments (MAUIs), Standard gamble (SG), Time trade-off (TTO), Systematic literature review

\footnotetext{
* Correspondence: noman.paracha@roche.com

${ }^{1}$ F. Hoffmann-La Roche AG, Basel, Switzerland

Full list of author information is available at the end of the article
}

(c) The Author(s). 2018 Open Access This article is distributed under the terms of the Creative Commons Attribution 4.0 International License (http://creativecommons.org/licenses/by/4.0/), which permits unrestricted use, distribution, and reproduction in any medium, provided you give appropriate credit to the original author(s) and the source, provide a link to the Creative Commons license, and indicate if changes were made. The Creative Commons Public Domain Dedication waiver (http://creativecommons.org/publicdomain/zero/1.0/) applies to the data made available in this article, unless otherwise stated. 


\section{Background}

Non-small cell lung cancer (NSCLC) is the most common form of lung cancer, occurring in $85-90 \%$ of lung cancer cases [1], and includes adenocarcinoma (40\% of all lung cancers), squamous cell carcinoma (25-30\%) and large cell carcinoma (10-15\%) [2]. NSCLC is staged according to the American Joint Committee on Cancer/ Union for International Cancer Control system [3], and measurement of lesions follows the Response Evaluation Criteria in Solid Tumors (RECIST) [4]. Approximately $40 \%$ of patients will have metastatic NSCLC (mNSCLC) at diagnosis [5], which includes cancers found in the lung and in the lymph nodes in the middle of the chest (defined as stage IIIA and IIIB; no distant metastasis), and cancers that have spread to both lungs or to another part of the body (defined as stage IV; distant metastasis) [6, 7].

Treatment is recommended according to the stage of mNSCLC, but treatment options are limited in the later stages of disease [7, 8]. Five-year survival rates are considerably lower in later than in earlier stages of NSCLC (stage IA, 45\%; stage IIIA, 14\%; stage IIIB, 5\%; stage IV, 1\%) [9]. Moreover, symptoms such as coughing and wheezing, chest pain, hoarseness and weight loss can severely reduce functional independence in patients with mNSCLC [10, 11]. Patient-reported health-related quality of life (HRQoL) provides an overall evaluation of health, well-being and daily functioning, and is impaired in patients with mNSCLC owing both to the disease and to treatment sequelae. Maintenance or improvement of HRQoL is an important treatment goal [12].

HRQoL can be expressed as a health state utility value (HSUV) ranging from 0 (death) to 1 (full health). If the health state is considered to be worse than death, health states can be valued at less than 0 . Utility values are key drivers in cost-effectiveness analyses because estimates of quality-adjusted life-years (QALYs) are obtained by multiplying HSUVs for each health state by the time spent in that health state. Estimates of cost per QALY are highly sensitive to the choice of HSUV. It is therefore important to identify specifically those HSUVs that have been derived using methods acceptable to health technology assessment (HTA) authorities [13].

HSUVs can be derived using a range of instruments and techniques $[14,15]$. In brief, instruments include: generic preference-based measures such as the EQ-5D-3 L [16] or EQ-5D-5 L [17], Health Utilities Index (HUI) [18], 6-dimension Short-Form Health Survey (SF-6D) [19], Assessment of Quality of Life instrument (AQoL) [20], 15-dimensional HRQoL measure [21], Quality of Well-Being scale [22], and multi-attribute utility instrument; as well as directly elicited standard gamble (SG), time trade-off (TTO) and visual analogue scale (VAS, e.g. EuroQoL VAS [EQ-VAS]). Mapping algorithms may also be used to convert values obtained from a condition-specific questionnaire to a generic preference-based measure; or to convert data from the 12- or 36-item Short-Form Health Survey (SF-12 or SF-36) to SF-6D [23]. Techniques may vary in terms of whose health is being measured (a patient's or a caregiver's), who responds to the questionnaire or, if using vignettes, who considers the health-state description (the patient regarding their own health, a patient with a different disease, the patient's closest caregiver, another caregiver, a physician or another healthcare provider). For preference-based measures, variation can stem from who values the health state (e.g. UK general population sample) and which choicebased method is used in this valuation (SG or TTO).

HTA bodies including the UK National Institute for Health and Care Excellence (NICE) [24, 25], the Scottish Medicines Consortium (SMC) [26], the Canadian Agency for Drugs and Technologies in Health (CADTH) [27], the French Haute Autorité de Santé (HAS) [28] and the Australian Pharmaceutical Benefits Advisory Committee (PBAC) [29] have stated preferences for HSUV methodology. Across these agencies, there is a preference for HSUVs estimated using generic preference-based measures. NICE has a strong preference for EQ-5D, as this reduces variability induced when different instruments are used between different disease areas. Agencies also strongly prefer patients to be the respondents, as patients can best describe their own health state. Finally, valuation estimated using a country-specific general-population tariff via a choice-based elicitation technique such as SG or TTO is preferred, as this represents societal preferences.

This systematic review had three main aims: first, to identify HSUVs for adults with previously treated mNSCLC, by treatment line and health state, and to evaluate the relevance of each health state to patients, for example, line of treatment, adverse events (AEs), response status and prognostic factors; second, to identify relevant disutilities or utility decrements associated with adverse events (irrespective of line of treatment or health state). Finally, the suitability of the HSUVs according to HTA reference case was explored and the quality of the HSUVs assessed.

\section{Methods}

\section{Study design and search strategy}

A systematic review of HSUVs in mNSCLC was undertaken to identify HSUV studies in any treatment line. Studies, published either as full papers or as conference abstracts, in patients previously treated for mNSCLC were selected for further analysis. The following databases were searched: Embase (1974 to 7 September 2016); MEDLINE $^{\oplus}$ (1966 to 7 September 2016); MEDLINE In-Process and e-publications ahead of print (database inception to 7 September 2016); and the Cochrane Library (including the Cochrane Database of Systematic Reviews, the Database of Abstracts of Reviews of Effects, 
the Cochrane Central Register of Controlled Trials, the National Health Service Economic Evaluation Database and the HTA database; 1968 to 7 September 2016).

Search strings are summarized in Additional file 1: Table S1, and were constructed not only to find utilities in mNSCLC (using a wide range of NSCLC and mNSCLC terms combined with the HSUV filter adapted from Arber et al. 2015 [30]) but also to identify all relevant disutilities or utility decrements associated with AEs/comorbidities. To ensure that estimates would be available from previously treated mNSCLC populations for all AEs or comorbidity health states relevant to the experience of such patients, the strings were designed to search for disutilities or decrements from a broader group of populations, as follows: from lung cancer; for progressive disease disutilities from advanced/metastatic cancer; for disutilities associated with the most common sites of metastasis from the lung (bone, respiratory system, nervous system, adrenal gland and liver) from advanced cancer; for disutilities associated with AEs or toxicities of cancer therapy; and disutilities associated with specific grade 3-4 AEs known to occur with cancer treatments from advanced cancer populations (pneumonia, pneumonitis, increased aspartate aminotransferase, febrile neutropenia, neutropenia, infection, sepsis, fatigue, lethargy, nausea, vomiting, ulcers, stomatitis, gastrointestinal disturbance, diarrhoea, visual disturbance, hearing loss, hair loss, psychological/self-esteem changes, rash, anaemia, bleeding and hypertension). From the identified disutilities/decrements for each $\mathrm{AE} / \mathrm{co}$-morbidity health state, those from the most relevant population available could be selected following an order of decreasing population specificity from first-line mNSCLC to NSCLC, lung cancer and advanced/metastatic cancer (Fig. 1).

\begin{tabular}{|c|c|c|c|}
\hline \multirow{5}{*}{ Advanced/mNSCLC } & - Stage IV 2L: UK & $\begin{array}{l}\text { Grade III/IV neutropenia, febrile neutropenia, } \\
\text { fatigue, nausea and vomiting, diarrhoea, } \\
\text { hair loss, rash }\end{array}$ & (Nafees [69]) \\
\hline & - Stage IV LNS: UK & $\begin{array}{l}\text { Neutropenia, febrile neutropenia, nausea, } \\
\text { diarrhoea, rash, stomatitis and neuropathy }\end{array}$ & (Tabberer [52]) \\
\hline & - Stage IV LNS: UK & Severe symptoms for cough, dyspnoea, pain & (Doyle [65]) \\
\hline & $\begin{array}{l}\text { - Stage IV } 1 \mathrm{~L}: \text { UK } \\
\text { + multinational }\end{array}$ & $\begin{array}{l}\text { Grade III/IV neutropenia, febrile neutropenia, } \\
\text { fatigue, nausea and vomiting, diarrhoea, } \\
\text { hair loss, rash, bleeding, hypertension }\end{array}$ & (Nafees [68]) \\
\hline & - Stage IV 1L: USA & $\begin{array}{l}\text { Neutropenia, pneumothorax, haemorrhage, } \\
\text { thrombocytopenia, thrombosis }\end{array}$ & (Handorf [70]) \\
\hline Early stage NSCLC & - LNS/early stage & Grade III+ dyspnoea & (Grutters [44]) \\
\hline $\begin{array}{l}\text { Advanced/mLC } \\
\text { (NSCLC + SCLC) }\end{array}$ & $\begin{array}{l}\text { - Stage IIIB/IV LC } \\
\text { with BM: Japan }\end{array}$ & $\begin{array}{l}\text { Average disutility for SREs (pathologic fracture, } \\
\text { radiation or surgery to bone lesion, spinal cord } \\
\text { compression or hypercalcaemia) }\end{array}$ & (Yokoyama [55]) \\
\hline$L C+B C$ & - LC + BC: USA & $\begin{array}{l}\text { Chemotherapy-related limited nausea, limited } \\
\text { vomiting, limited nausea and vomiting, } \\
\text { continuous nausea and vomiting }\end{array}$ & (Grunberg [58]) \\
\hline Advanced cancer & $\begin{array}{l}\text { - Stage IV cancer } \\
\text { with BM: UK, Canada }\end{array}$ & $\begin{array}{l}\text { Specific SRE disutilities for spinal cord } \\
\text { compression with/without paralysis, fracture } \\
\text { of leg, fracture of rib, fracture of arm, radiation } \\
\text { treatments, surgery to stabilize bone }\end{array}$ & (Matza [67]) \\
\hline Cancer & $\begin{array}{l}\text { - Cancer unclear stage: } \\
\text { UK }\end{array}$ & Anaemia (by $\mathrm{Hb}$ level) & (Lloyd [59]) \\
\hline Not reported & $\begin{array}{l}\text { - Lilly and Roche NSCLC } \\
\text { NICE submissions }\end{array}$ & $\begin{array}{l}\text { Anaemia (single disutility), i.v. treatment } \\
\text { mode, oral treatment mode }\end{array}$ & (Westwood [71]) \\
\hline
\end{tabular}

Fig. 1 Studies reporting adverse event health state (dis) utilities by patient population and country. Abbreviations: $1 L$ first line, $2 L$ second line, $B C$ breast cancer, BM bone metastasis, Hb haemoglobin, i.v. intravenous, LC lung cancer, LNS line of treatment not specified, $m L C$ metastatic lung cancer, mNSCLC metastatic non-small cell lung cancer, NICE National Institute for Health and Care Excellence, NSCLC non-small cell lung cancer, SCLC small cell lung cancer, SRE skeletal-related event 
Using the term "NSCLC" or "non-small cell lung cancer", manual searching of the EQ-5D website, of the School of Health and Related Research Health Utilities Database (ScHARRHUD) and of major pharmacoeconomic and clinical conferences in 2015-2016 was conducted on 3 and 5 December 2016. Conferences included: the International Society for Pharmacoeconomics and Outcomes Research (ISPOR) International Meetings and European Congresses; the HTA International Annual Meetings (HTAi); the Society for Medical Decision Making (SMDM) North American Meetings and European Conferences; the American Society of Clinical Oncology (ASCO) Meetings; and the European Society for Medical Oncology (ESMO) Congresses. Bibliographic reference lists of relevant systematic reviews from 2010 onwards were searched and of relevant cost-utility analyses, and HTA reports from various bodies identified in a parallel economic systematic review, including: NICE; SMC; All Wales Medicines Strategy Group (AWMSG); PBAC; CADTH; Institut National d'Excellence en Santé et en Services Sociaux; pan-Canadian Oncology Drug Review (pCODR); and HAS.

The PICOS (patient, intervention, comparator, outcome, study) statements for study inclusion and exclusion criteria are summarized in Table 1. Although, second- and later-line data were of primary interest, studies that reported utilities for patients with mNSCLC who were either treatment-naïve or in receipt of maintenance first-line treatment were included for reference at the first screening but data were not extracted. These studies are listed in Additional file 2: Table S2.

Mapping from condition-specific to preference-based studies was not sought because it was anticipated that sufficient published utility and EQ-5D data would be available to populate the health states of an economic model, and because results based on mapping algorithms sit lower in the acceptance hierarchy used by some HTA authorities (Additional file 3: Figure S1). We have acknowledged NICE's stated preference for EQ5D-3 L data over EQ-5D-5 L (Additional file 3: Figure S1) and provide detailed information of the instrument used for generating data for each identified study in Table 2 [31].

\section{Study selection}

The screening process complied with the 2009 Preferred Reporting Items for Systematic Reviews and Meta-Analyses (PRISMA) guidelines [32]. Publications were de-duplicated using EndNote (Clarivate Analytics, Philadelphia, PA, USA) and using Rayyan (Qatar Computing Research Institute, Doha, Qatar) [33], an internet-based reference management system endorsed as suitable for systematic review screening by the European Network for HTA [34]. Abstracts and titles of papers were screened by one reviewer, and a 50\% sample check conducted by a second reviewer; exclusion criteria are summarized in Table 1 . The full texts of papers potentially meeting the selection criteria were screened by one reviewer, and a $50 \%$ sample check was conducted by a second reviewer. Discrepancies were discussed between reviewers, and any unresolved disputes were referred to a third reviewer.

\section{Data extraction}

Data were collected using a piloted data-extraction sheet. Extraction was conducted by one reviewer, and priority data elements were quality checked by a second reviewer. The information extracted included study design, whether the selection criteria yielded a population that matched the target population (i.e. previously treated adult patients with mNSCLC), health state description, instrument type, instrument scale, HSUV or (dis) utility or decrement estimates and measure of variability (median with interquartile range or mean with standard error, standard deviation or 95\% confidence interval), derivation methods and if the data presented were appropriate for use in HTA submissions to NICE, SMC, CADTH, HAS and PBAC.

\section{Quality and relevance assessment}

The appropriateness of utilities reported for use in economic evaluations was determined by whether data met the requirements of the HTA body reference case; and the quality of utility estimates (based on sample size, response to the questionnaire, loss to follow-up, handling of missing data, and reporting of point and variance estimates, as discussed in NICE Decision Support Unit Technical Support Document 11 and its related publication [25, 35]; Additional file 4: Table S3). Any recommendation for, or rationale against, the use of specific utilities in a cost-utility analysis model in previously treated patients with $\mathrm{mNSCLC}$ was also taken into consideration in line with preliminary guidance from the ISPOR Health State Utility Good Practices Task Force [36].

\section{Results}

\section{Search yields}

Electronic database searches identified 1883 citations (1521 from MEDLINE/Embase, 144 from MEDLINE InProcess/e-publications and 218 from the Cochrane Library databases). After de-duplication (51 citations: 30 via Endnote and 21 via Rayyan) and title/abstract screening (1557 exclusions), 275 full-text papers were reviewed. Of these, 250 were excluded (21 of which were tagged as reporting first-line treatment; Additional file 2: Table S2), yielding 25 citations that were included from electronic sources. Manual searching identified 11 citations. In total, 36 articles were included, reporting 34 studies (Table 2). Two articles [37, 38] were linked to 
Table 1 Inclusion criteria

\begin{tabular}{|c|c|}
\hline Characteristic & Inclusion criteria \\
\hline Population & $\begin{array}{l}\text { Adult patients (aged } \geq 16 \text { years) } \\
\text { Locally advanced NSCLC or } \mathrm{mNSCLC} \text {, second/subsequent line } \\
\text { Locally advanced or metastatic NSCLC, line unspecified }\end{array}$ \\
\hline $\begin{array}{l}\text { Interventions/ } \\
\text { comparators }\end{array}$ & $\begin{array}{l}\text { Not relevant for QoL SR selection. Intervention-specific } \\
\text { utility data were noted as such during data extraction }\end{array}$ \\
\hline Outcomes & $\begin{array}{l}\text { For mNSCLC patients: } \\
\text { - individual (patient or caregiver) derived mean or median } \\
\text { health state utilities from indirect generic HRQoL measure } \\
\text { (EQ-5D }(-3 \mathrm{~L} \text { and }-5 \mathrm{~L}), \mathrm{SF}-6 \mathrm{D}, \mathrm{HUI}, \mathrm{HUI}, \mathrm{AQOL}, \mathrm{QWB}, 15 \mathrm{D} \text {, } \\
\text { MAUI) or direct valuation by } T T \mathrm{O}, \mathrm{SG} \text { or EQ-VAS } \\
\text { - SF-36 or SF-12 } \\
\text { - general public valuations of vignettes using } T \mathrm{TO} \text { or SG } \\
\text { For NSCLC or wider population: } \\
\text { - disutilities or decrements for AEs }{ }^{\mathrm{b}} \text { or progressive disease }\end{array}$ \\
\hline
\end{tabular}

Study design $\quad$ RCTs, non-RCTs, observational data

$\begin{array}{ll}\text { Date limits } & \text { Unlimited } \\ \text { Child citation } & \text { Citation linked to another paper but with unique data }\end{array}$

Duplicate citation

Publication type
Exclusion criteria

Population not of interest, e.g.

- in vitro data

- animal data

- mixed adult/child population or child population

- mixed disease populations without MNSCLC data reported separately

- not disease of interest

- $1 \mathrm{~L}$ mNSCLC data (treatment-naïve or maintenance first-line treatment) were excluded but tagged ${ }^{a}$

N/A

No outcome of interest:

- expert or healthcare provider (doctor, nurse) valuations of utilities

- utilities not relating to a specific health state

Study design not of interest:

- case reports, $n=1$ before-and-after studies

- PK/PD study only

- (Non-systematic) reviews

- SRs/NMAs

$-$

Child citation or sub-study with no unique data, determined at first or second pass

Duplicate/copy

Publication type not of interest e.g. editorials, commentaries, letters, notes, press articles, unless relevant data has been published in a letter, for example, that does not appear elsewhere in the literature

Confidential reports where unable to use report, or Hayes Inc. reports requiring purchase

Full text in language other than English or French with no English abstract or no abstract; or insufficient information in English language abstract of foreign language full paper to assess eligibility

\footnotetext{
${ }^{\mathrm{a}}$ To enable listing in the report

${ }^{b}$ Disutilities may be included for AEs, inconvenience of treatment or progressive health states from diseases outside NSCLC (preferably from lung cancer or from advanced/metastatic cancer) where no such data are available from patients with NSCLC

'SRs were kept in until the second pass, where the full paper's included studies were examined, after which the SR itself was excluded

Abbreviations: $1 \mathrm{~L}$ first line, $3 \mathrm{~L}$ 3-level, $5 \mathrm{~L}$ 5-level, $15 \mathrm{D}$ 15-dimensional health-related quality of life measure, $A E$ adverse event, $A Q 0 L$ Assessment of Quality of Life instrument, EQ-VAS EuroQoL visual analogue scale, HRQoL health-related quality of life, HUI2/3 Health Utilities Index Mark 2/3, MAUI multi-attribute utility instrument, $m N S C L C$ metastatic non-small cell lung cancer, N/A not available, NMA network meta-analysis, NSCLC non-small cell lung cancer, PD pharmacodynamic, PK pharmacokinetic, QoL quality of life, QWB Quality of Well-Being scale, RCT randomized controlled trial, SF-6D 6-dimension Short-Form Health Survey, SF-12/36

12/36-item Short-Form Health Survey, SG standard gamble, SR systematic review, TTO time trade-off, VAS visual analogue scale
}

other publications [39, 40], and were retained because they provided additional information. The study selection is summarized in a PRISMA flow chart in Fig. 2.

\section{Description of studies identified}

Among the 36 articles (34 studies) identified, 19 reported EQ-5D scores [37-55] (three studies further specified the instrument as EQ-5D-3 L $[39,41,56]$ and two as EQ-5D-5 L [44, 57]; Table 2), two reported SG or TTO directly elicited from patients [58, 59], two reported EQ-VAS scores only [57, 60], and one reported AQoL scores [61] (Table 2). Moreover, one study reported SF-12 scores for caregivers to patients with mNSCLC [62], eight reported HSUVs from valuations of vignettes made by members of the public using SG or TTO [59, 63-69] (one of which reported both general public-elicited SG and patient-elicited TTO) [59], and one reported disutility estimates based on expert opinion for pneumothorax, thrombocytopenia and thrombosis, adverse event health states for which disutilities were not available from other HSUV derivation methods [70]. A further two articles reported HSUVs but were unclear about how these were 


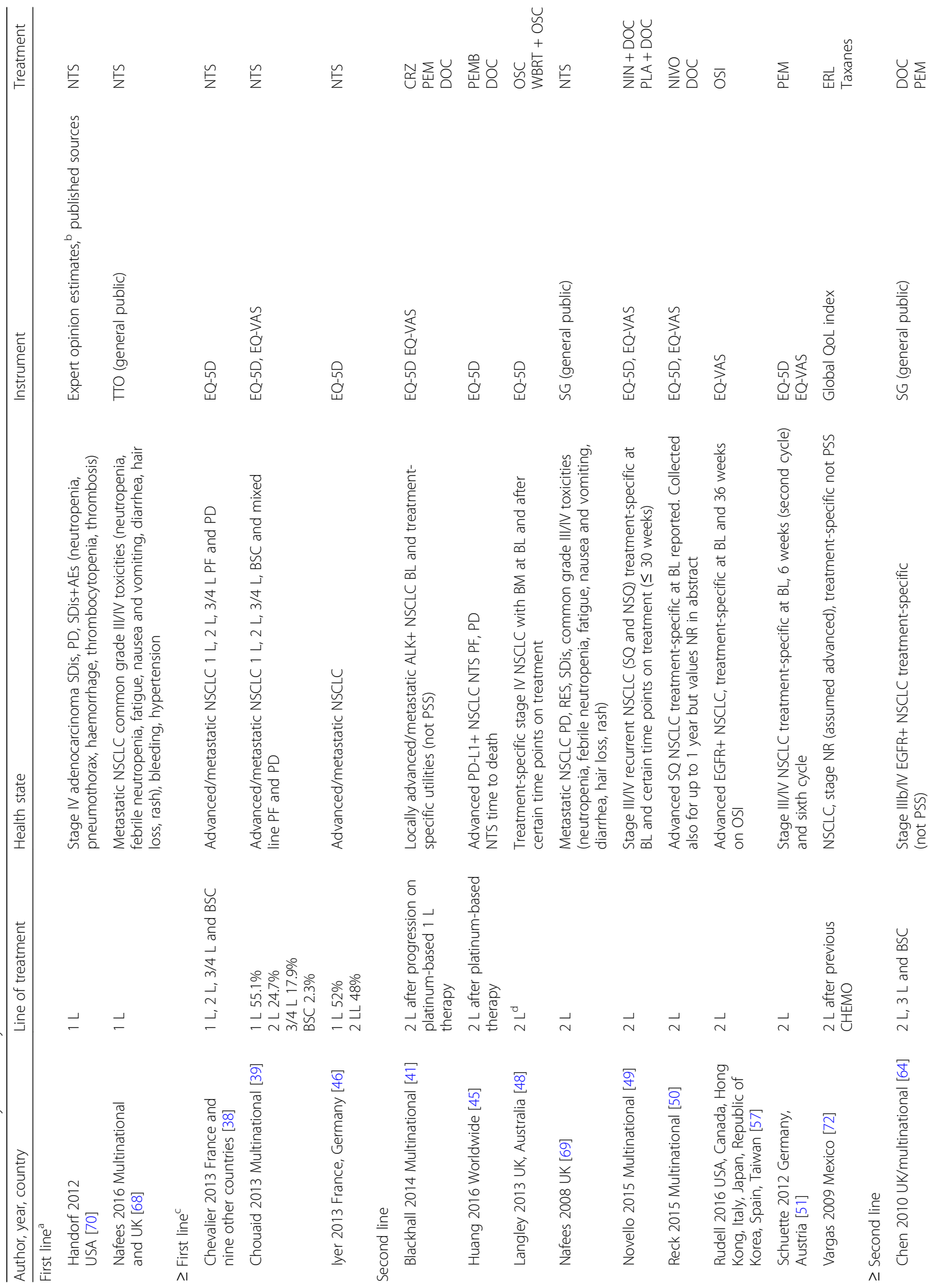




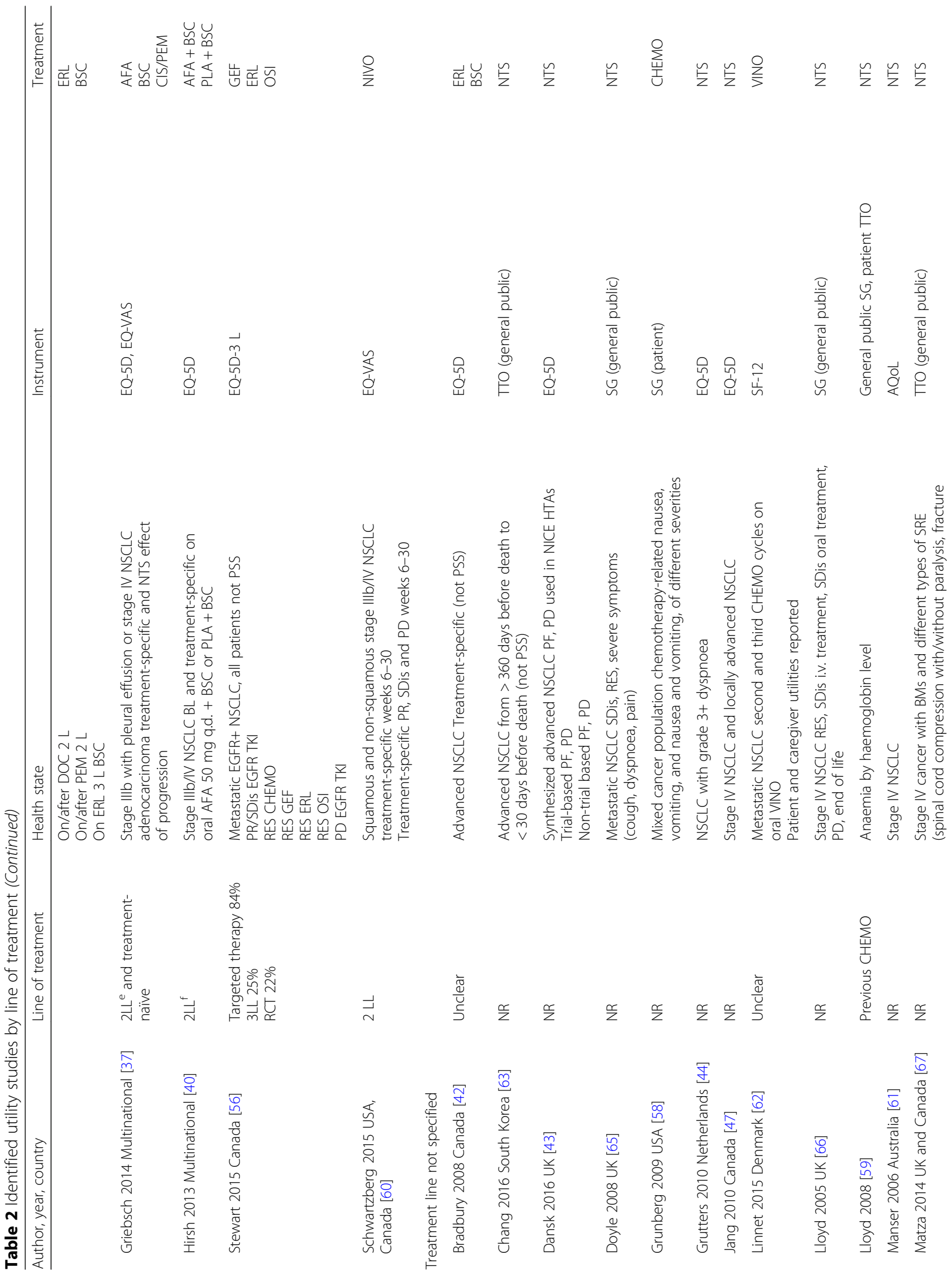




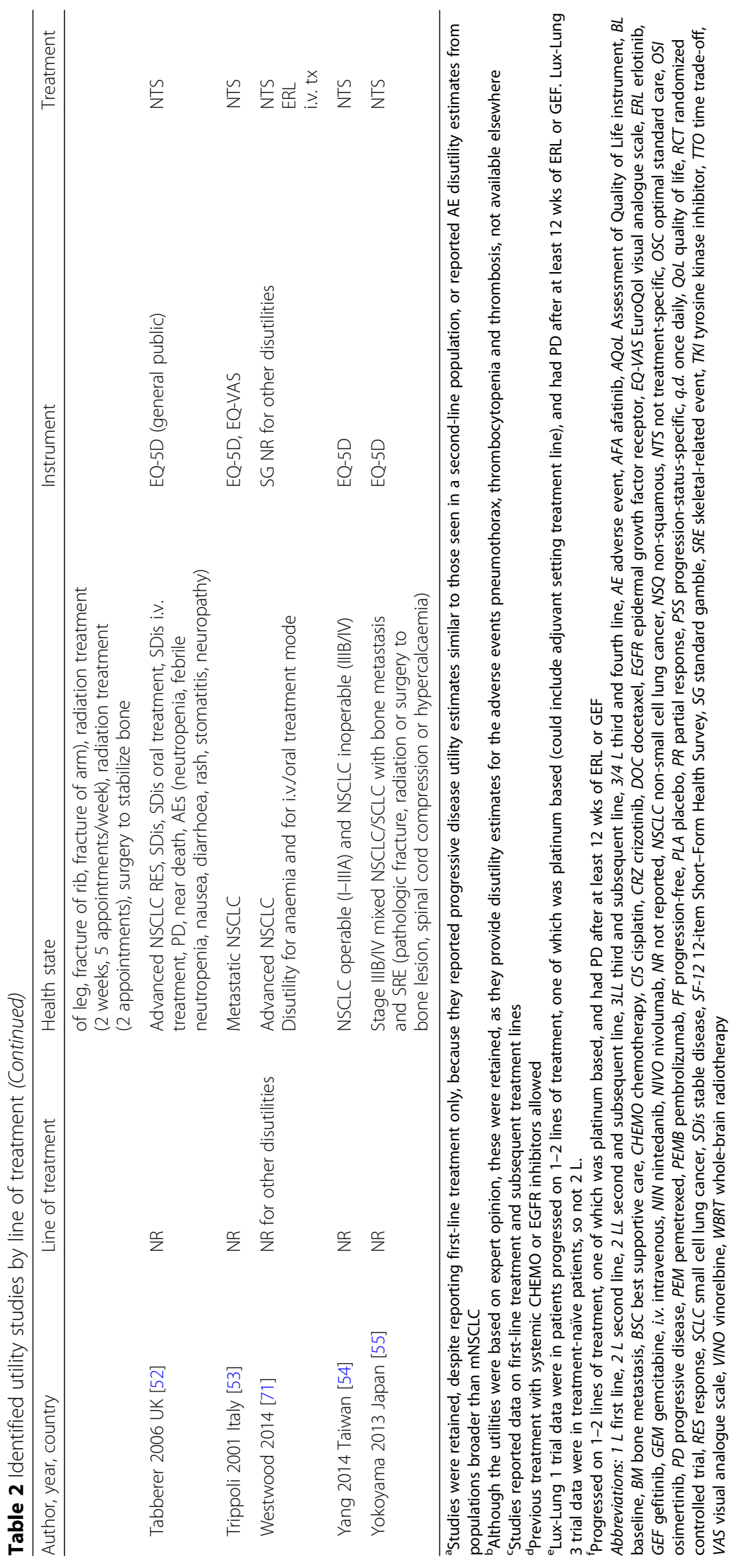


derived; one reported disutilities used in previous NICE submissions, for anaemia and for oral and intravenous treatment modes [71], and one reported a "global quality of life index" for second-line NSCLC [72].

Among the dataset, two studies were retained despite reporting first-line treatment only, because they reported AE disutility estimates from populations broader than mNSCLC $[68,70]$; three further studies that reported first-line data also reported on subsequent treatment lines [38, 39, 46]. Eleven studies focused exclusively on HSUVs associated with second-line treatment [41, 45, 48-51, 57, 59, 69, 71, 72], and five reported HSUVs in second-line and subsequent treatment $[37,40,56,60,73]$. Line of treatment was unspecified in 15 studies [42-44, 47, 52-55, 58, 61-63, 65-67].

\section{Relevant HSUVs by line of treatment}

Utilities were reported for a range of health state types: treatment-specific or not, RECIST response-based or not, time-on-treatment, time-till-death, or a combination of these. Details of HSUV estimates by treatment line are given in Table 3. Among patients receiving second-line or subsequent treatment for advanced
NSCLC or mNSCLC, mean HSUV estimates based on EQ-5D for stable/progression-free disease and for patients at baseline or pre-treatment were in the range $0.66-0.76[38,39,41,45,49,50]$; in the same group, mean values for patients with progressive disease were generally lower $(0.55-0.69)$ [38, 39, 45]. Among patients on treatment at this stage of disease and treatment line, the range of mean HSUVs based on EQ-5D was broad (0.53-0.82) [40, 41, 46, 51, 56], the highest value being associated with treatment with tyrosine kinase inhibitors $[41,56]$. A similar range of HSUV values was seen among patients being treated for advanced NSCLC or mNSCLC when the treatment line was unspecified (0.53$0.77)[42,47,52,53]$. Only three papers specified using EQ-5D-3 L [39, 41, 56] and only two EQ-5D-5 L [44, 57].

Disutilities for progression from a stable state were -0.056 or -0.065 by EQ-5D, both from Griebsch et al. [37], or -0.1798 by general population-derived SG [69]. Overall, HSUVs varied not only by treatment line and disease state, but also by the treatment received under the same health state (potentially reflecting differences in safety profiles) and by the instrument/tariff used to derive the HSUV.

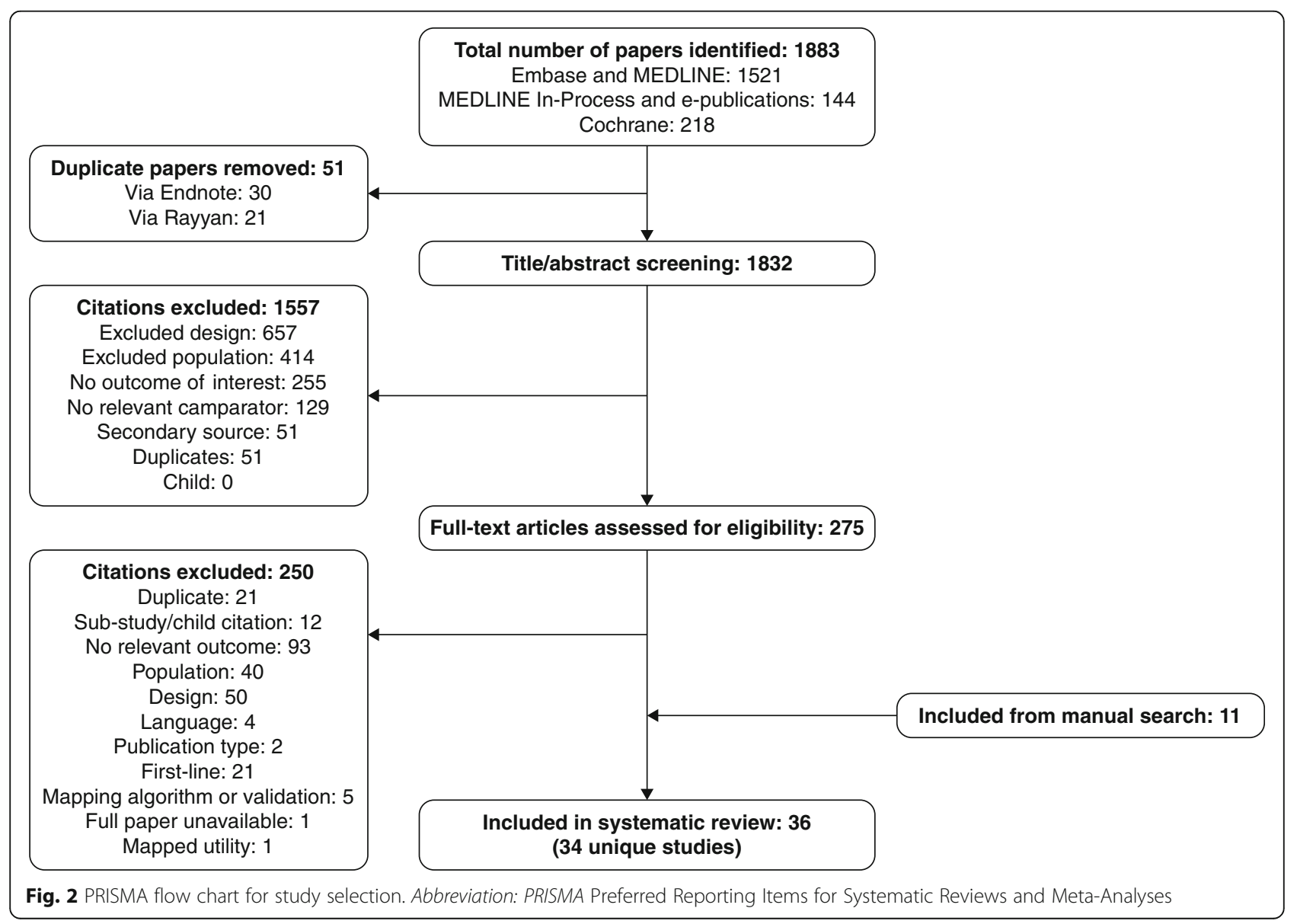




\section{Relevant disutilities and decrements}

Eleven studies identified in this systematic review reported disutilities or decrements for $\mathrm{AE}$ health states $[44,52,55,58,59,65,67-71]$. Only two studies reported disutilities specifically associated with second-line treatment $[69,71]$, and another two studies did not specify the treatment line $[44,65]$; disutility and decrement data are summarized in Table 4. Utility-incorporating decrements were identified for the following AEs in the context of second-line "stable disease" or second-line "responding": diarrhoea, fatigue, febrile neutropenia, hair loss and nausea/vomiting. Disutilities associated with second-line treatment were reported for the following events [69]: "moving from stable to progressive state" $(-0.18)$, neutropenia $(-0.09)$, febrile neutropenia $(-0.09)$, fatigue $(-0.07)$, nausea/vomiting $(-0.05)$, diarrhoea $(-0.05)$, hair loss $(-0.04)$ and rash $(-0.03)$.

Further recommended sources of AE health state (dis) utilities were as follows (Fig. 1): in $2 \mathrm{~L}$ from general population SG in Nafees et al. 2008 [69]; in metastatic NSCLC (line unspecified) from general population SG in Doyle et al. 2008 [65]; in $1 \mathrm{~L}$ from patients without NSCLC using directly elicited TTO in Nafees et al. 2016 [68]; in $2 \mathrm{~L}$ in NSCLC as reported in Westwood et al. 2014 [71]; in cancer with bone metastases for skeletal-related events from general population TTO in Matza et al. 2014 [67]; stage IV NSCLC in 1 L from expert opinion estimates in Handorf et al. 2012 (expert-opinion-derived utilities from this study were included, as they are the only source of estimates for pneumothorax, thrombocytopenia and thrombosis disutilities) [70]; and anaemia from general population SG or from patient-derived TTO in Lloyd et al. 2008 [59].

\section{Description of HTA-relevant HSUVs and disutilities}

Of the 36 publications, 13 provided HSUVs that meet the NICE reference case or are considered acceptable to the HTA agencies of interest [37-40, 42, 45, 46, 49, 53, $56,58,64,69]$, based on the measurement technique for generation of HSUVs, as outlined in Additional file 3: Figure S1. The main characteristics of these studies are presented in Table 3. These 13 publications reported data from multinational studies [37-40, 45, 49, 64], and from Canada [42, 56], France/Germany [46], USA [58], Italy [53] and the UK [69]. In these studies, HRQoL was measured using EQ-5D [37-40, 42, 45, 46, 49, 53, 56], EQ-VAS [37, 39, 40, 49] and SG [58, 64, 69]. The HTA suitability of disutilities and decrements for $\mathrm{AE}$ health states in previously treated patients are reported in Table 4.

\section{Discussion}

Economic evaluation, particularly cost-utility analysis, provides important information for guiding decisionmaking in health care, and its use in HTA is increasing globally. Such evaluation includes examination of the time spent in different disease states and uses an HSUV for each disease state to calculate QALYs; HSUVs therefore play a key role in economic evaluation. As summarized in Additional file 3: Figure S1, NICE, SMC, $\mathrm{CADTH}, \mathrm{HAS}$ and PBAC prefer utilities to be estimated using a generic preference-based instrument, with health states described by patients through use of a questionnaire, and with the health state valued using a country-specific tariff that reflects societal preferences. As the aim of this systematic review was to evaluate the experience of adults with previously treated mNSCLC, the synthesis of health state utility estimates was outside its scope. However, the findings presented here may provide a basis for generation of an accurate estimate of the mean HSUV for use in economic evaluations [74, 75].

This systematic review identified HSUVs relevant to the experience of previously treated adult patients with mNSCLC. Search strings were designed to allow (dis) utilities from a broader population (including lung cancer, advanced/metastatic cancer and specific metastases common in patients with lung cancer). In the absence of second-line mNSCLC (dis) utilities, alternatives were selected with decreasing population specificity and relevance from first-line mNSCLC, NSCLC, lung cancer or advanced/metastatic cancer, as outlined in Fig. 1. Ordering the HSUVs by line of treatment reflects the practice of switching treatment at progression. However, for the newer immunotherapies, patients may remain on treatment post-progression, and their HRQoL may remain at pre-progression levels. Thus, HSUVs estimated for progression status-specific health states from patients receiving chemotherapy may not be suitable to apply to the equivalent health states when patients receive immunotherapy.

In total, the 36 identified articles reported 591 HSUVs relevant to the experience of previously treated adult patients with mNSCLC, and 11 of these studies reported a total of 195 disutilities or decrements for $\mathrm{AE}$ health states that are relevant to the experience of patients with mNSCLC. The range of HSUVs identified for comparable health states, such as progression-free/stable disease among patients treated second-line for advanced/metastatic NSCLC [39, 45], highlights how differences in study type, tariff, health state and the measures used can drive variation in HSUV estimates. For instance, disutilities for progression from a stable state were -0.056 or - 0.065 using EQ-5D, [37] or - 0.1798 by general-population-derived SG. [69] To overcome such variations, where possible, HSUV studies should seek to use instruments, respondents and valuation populations that are most acceptable to HTA bodies. However, there are instances where variation in methods can be justified. For example, disutility values derived from vignettes and a general public sample were used by Nafees et al. [69], 


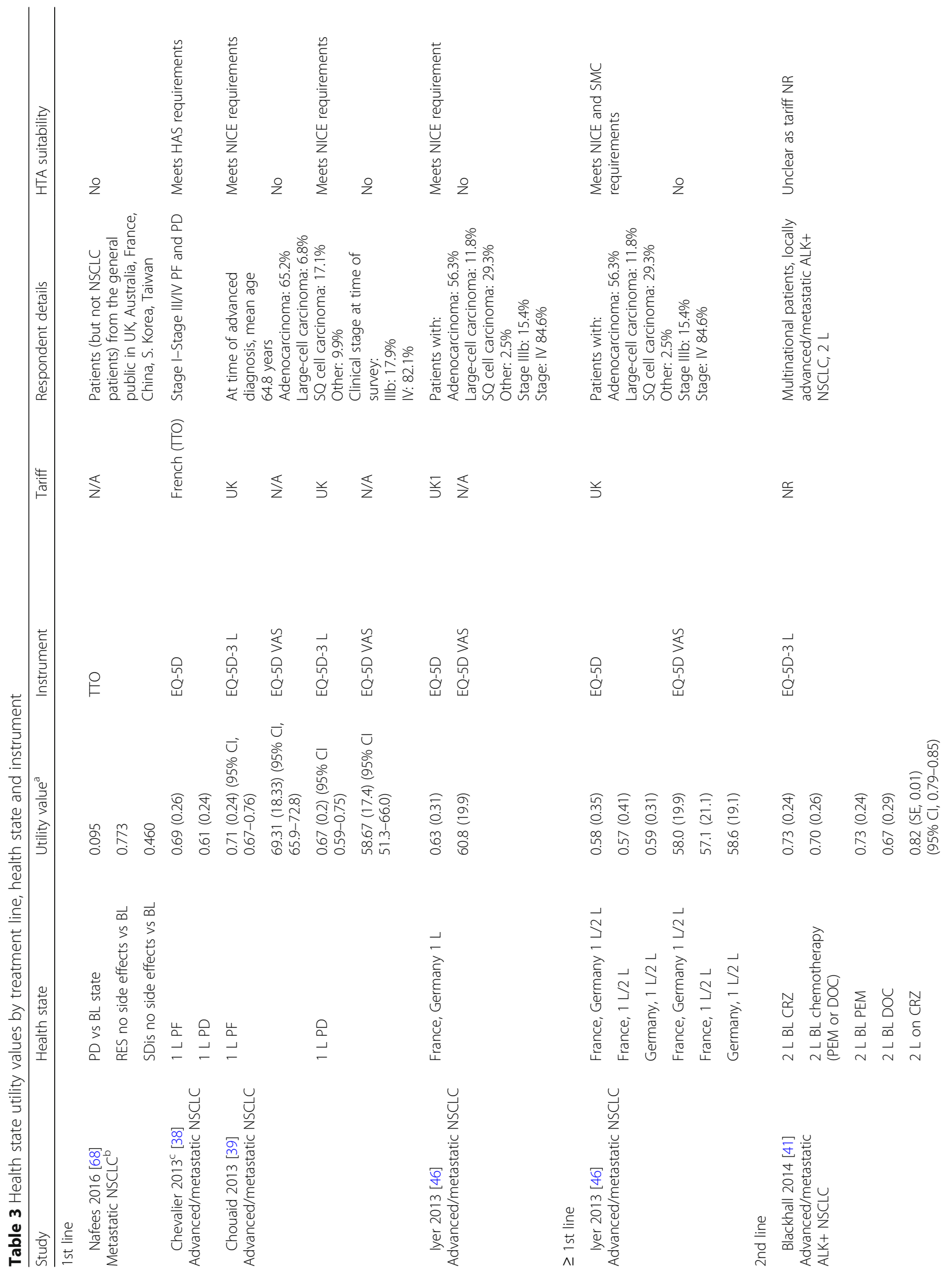




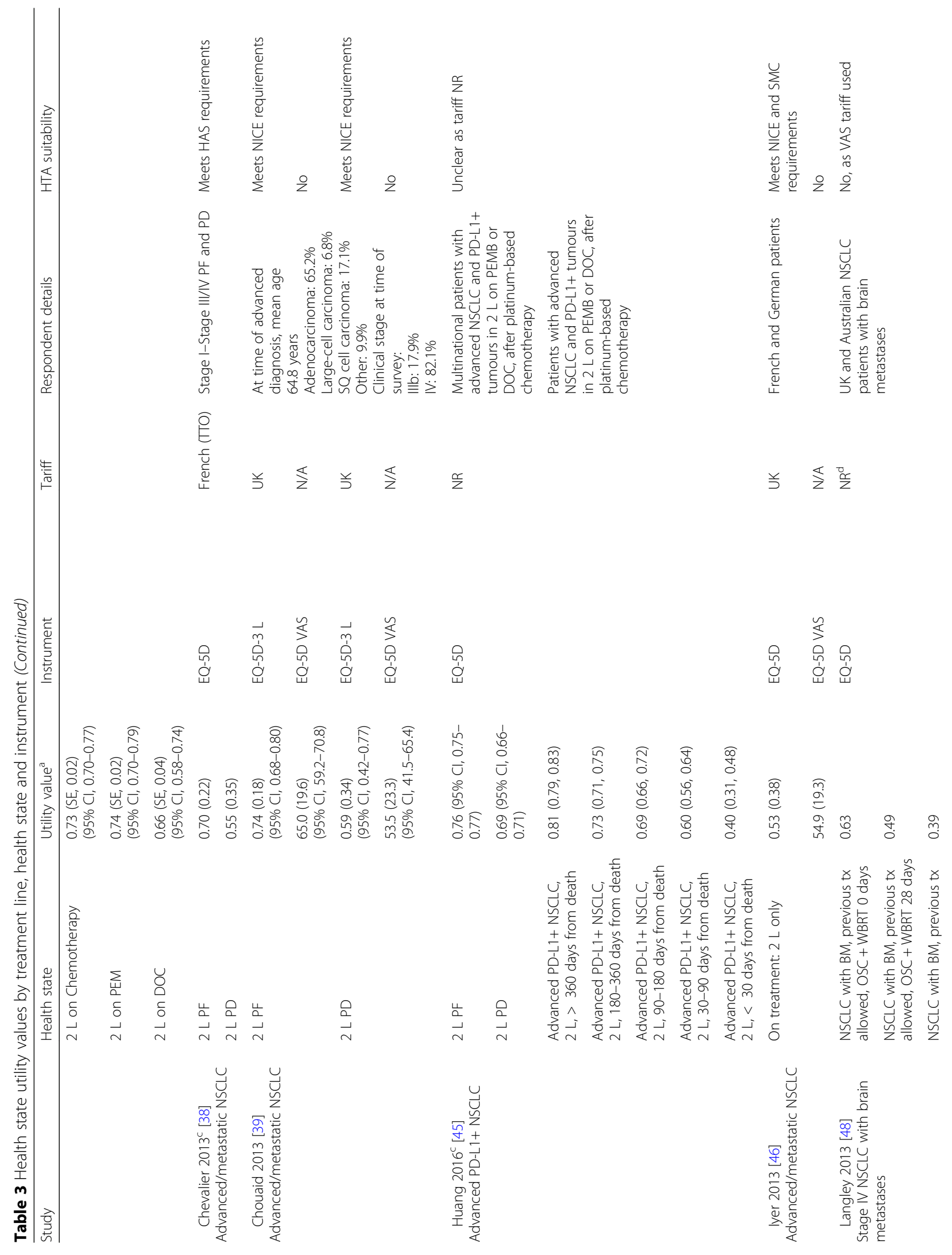




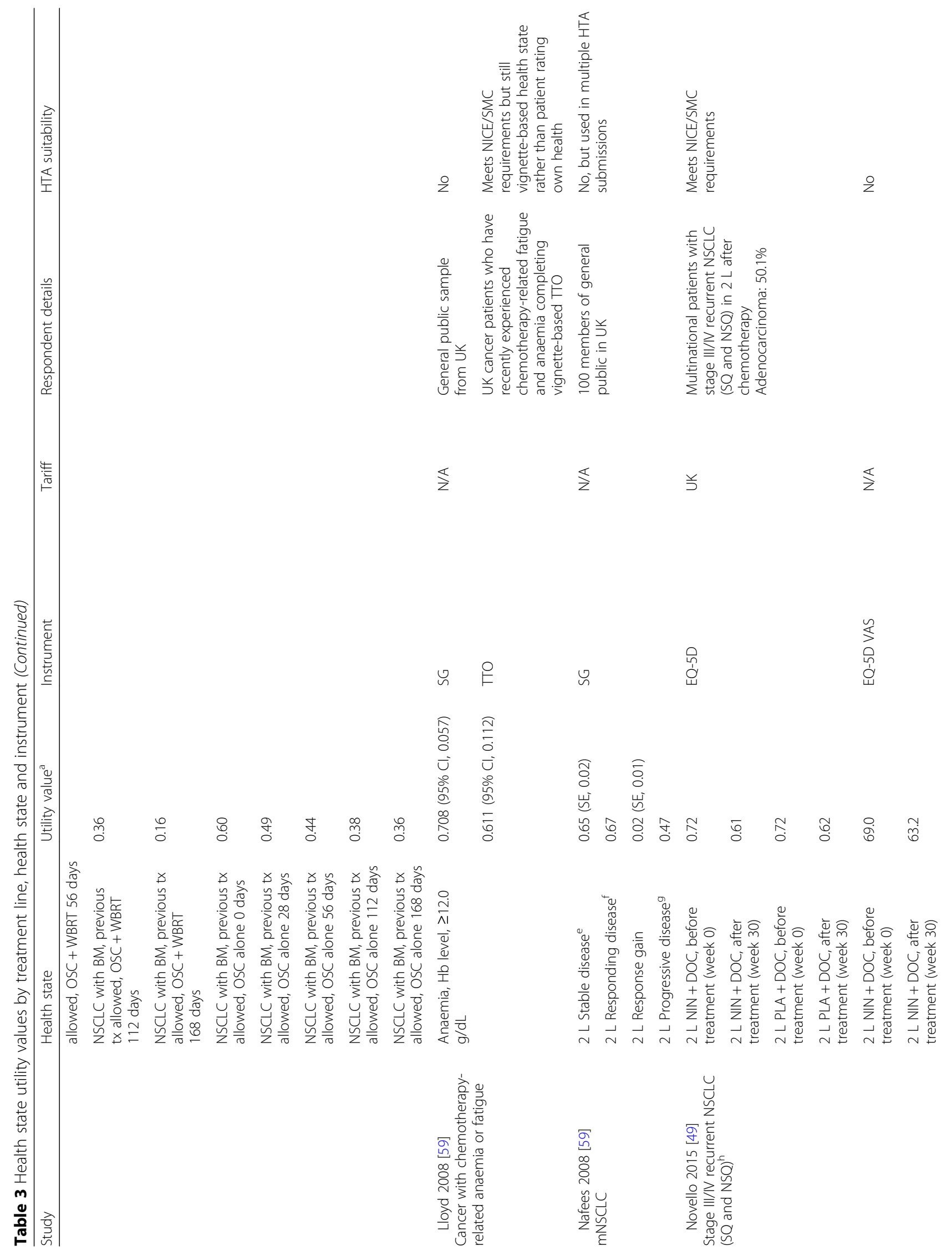




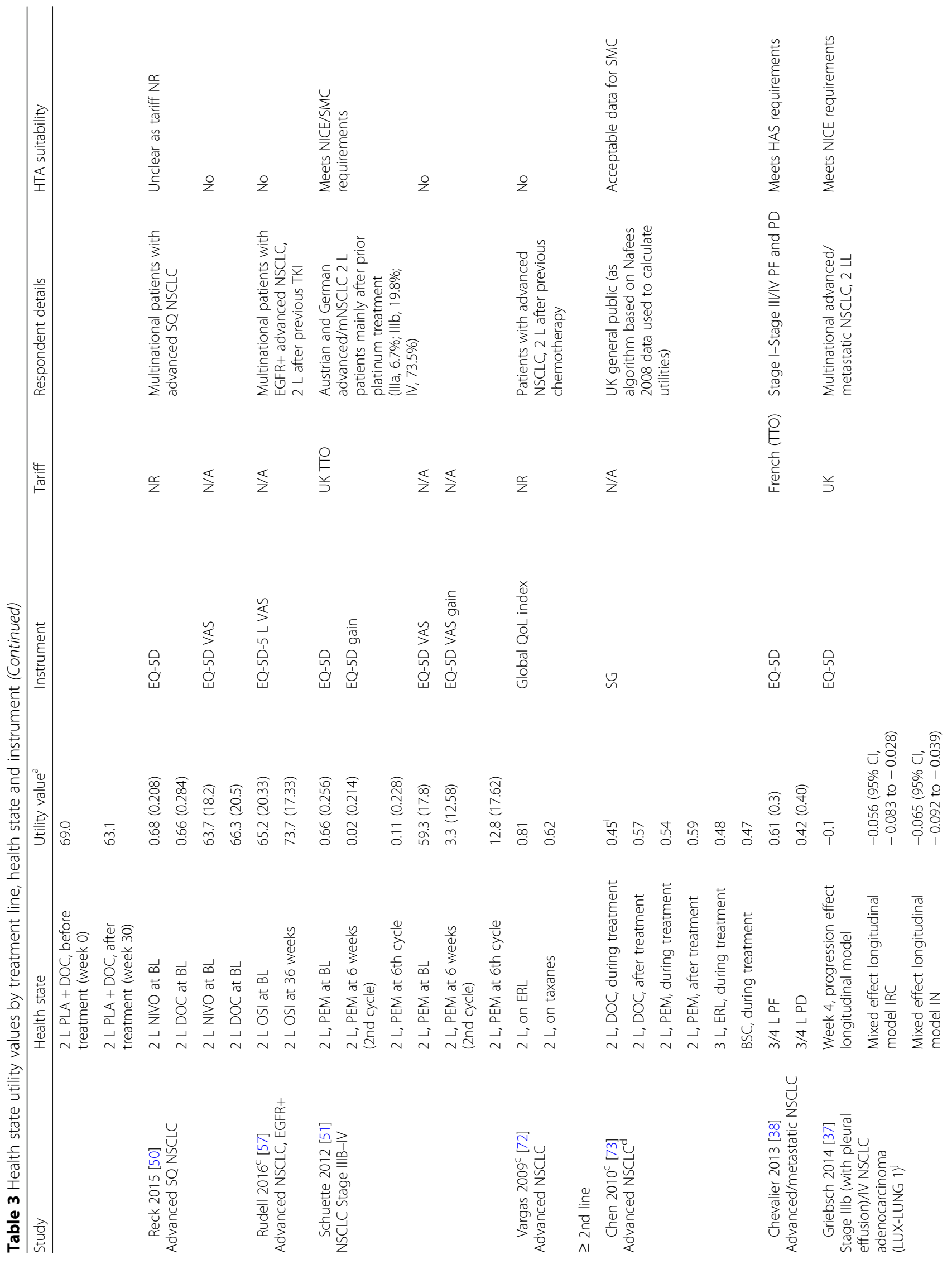




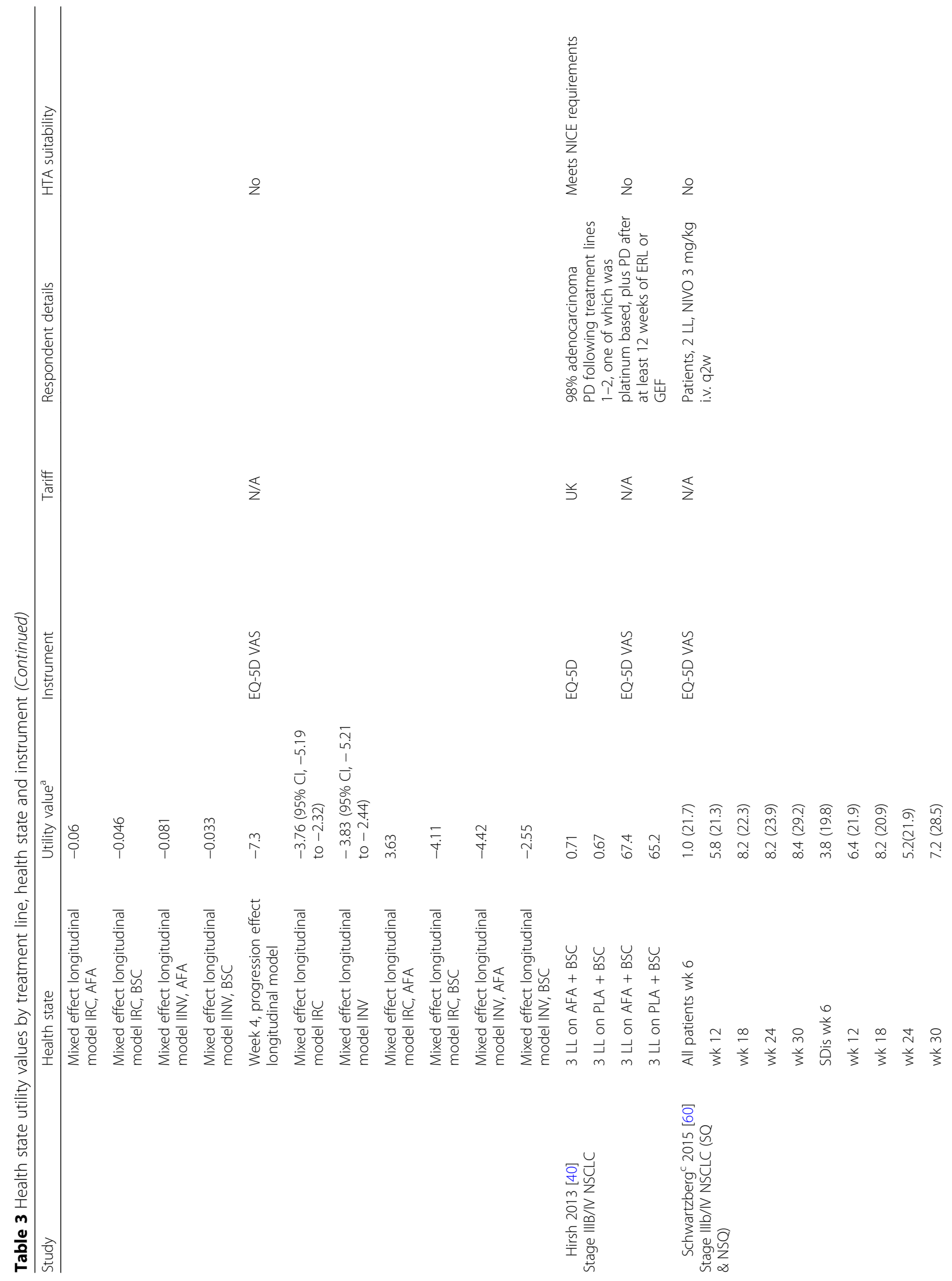




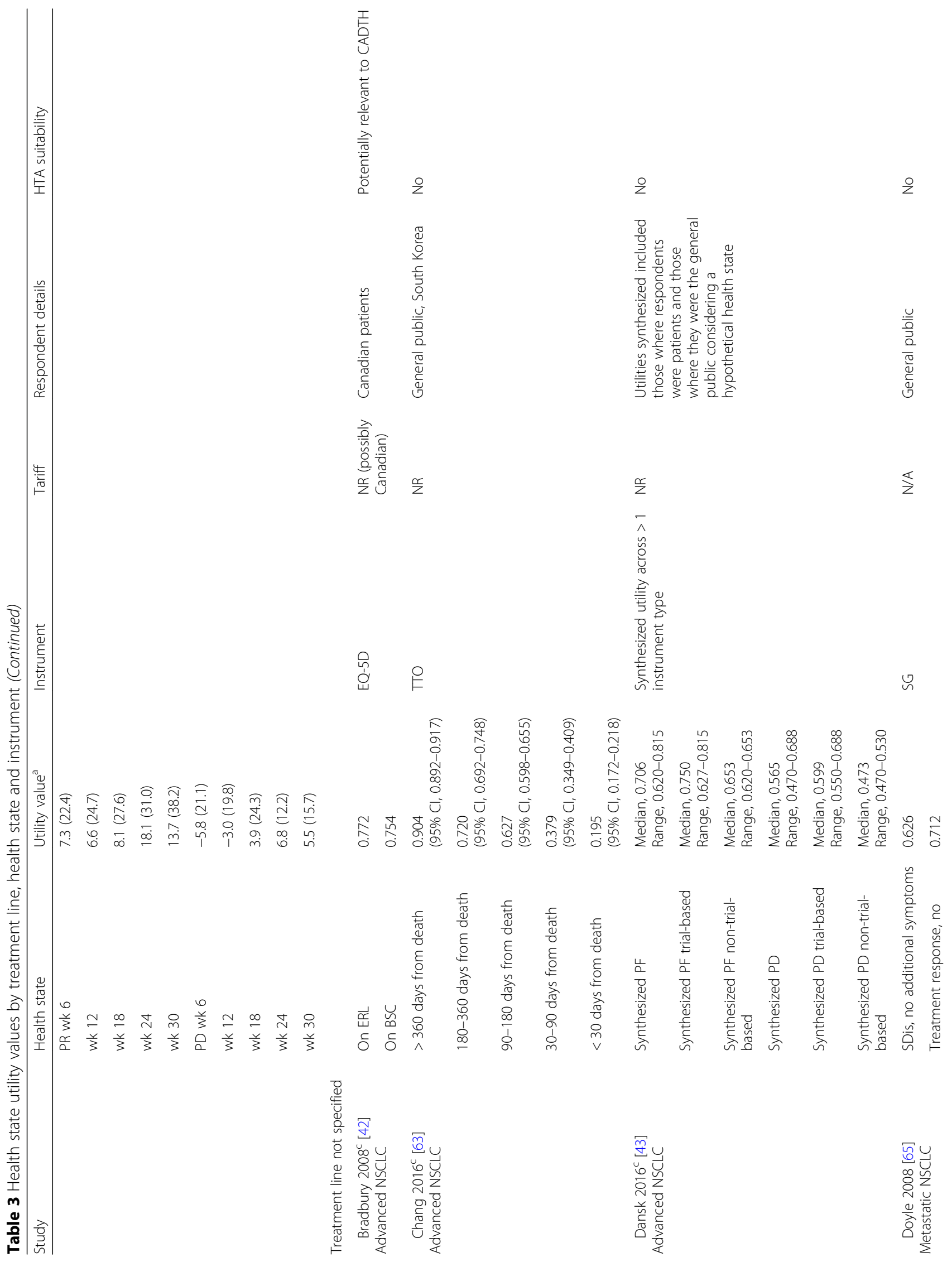




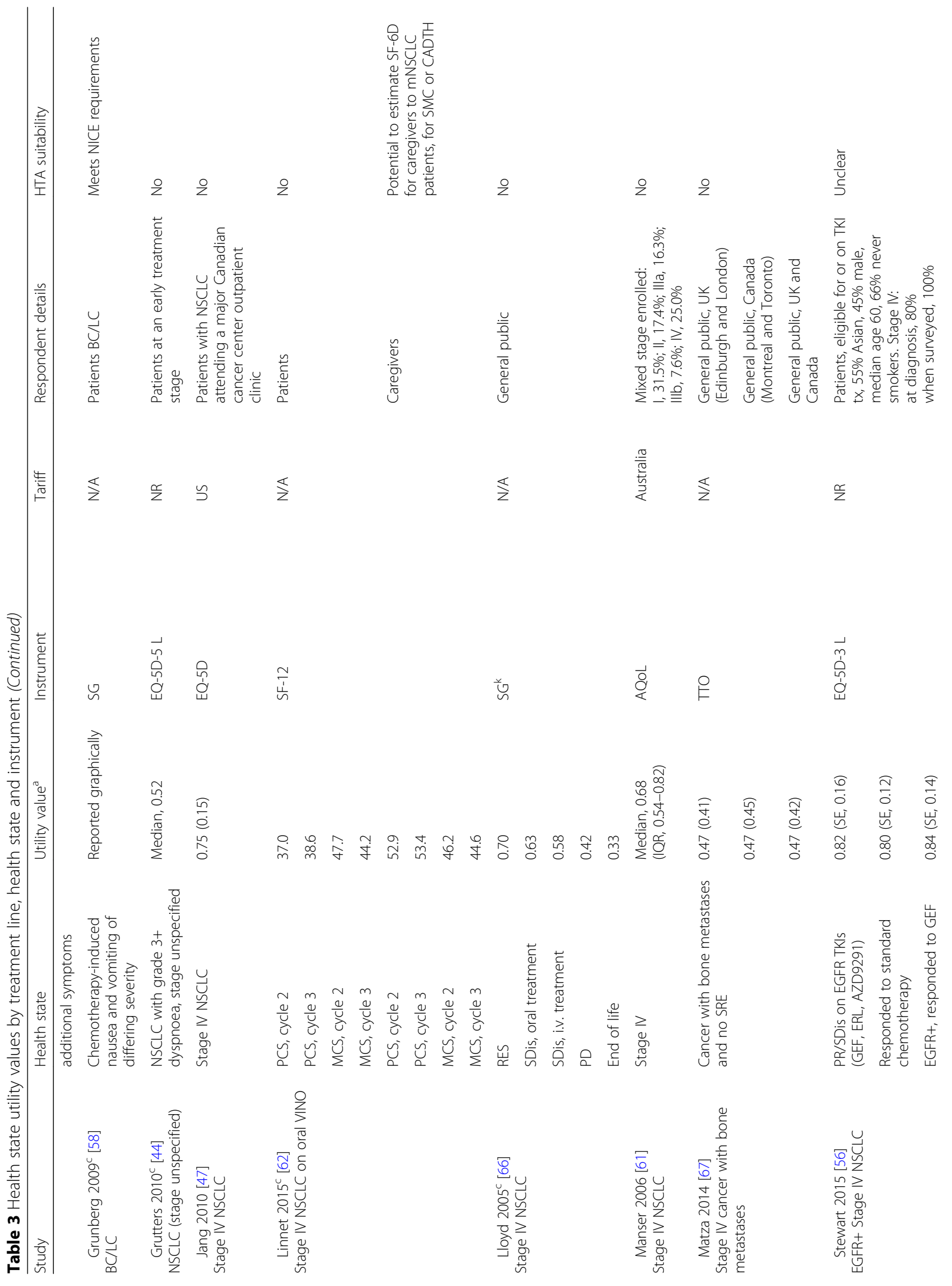




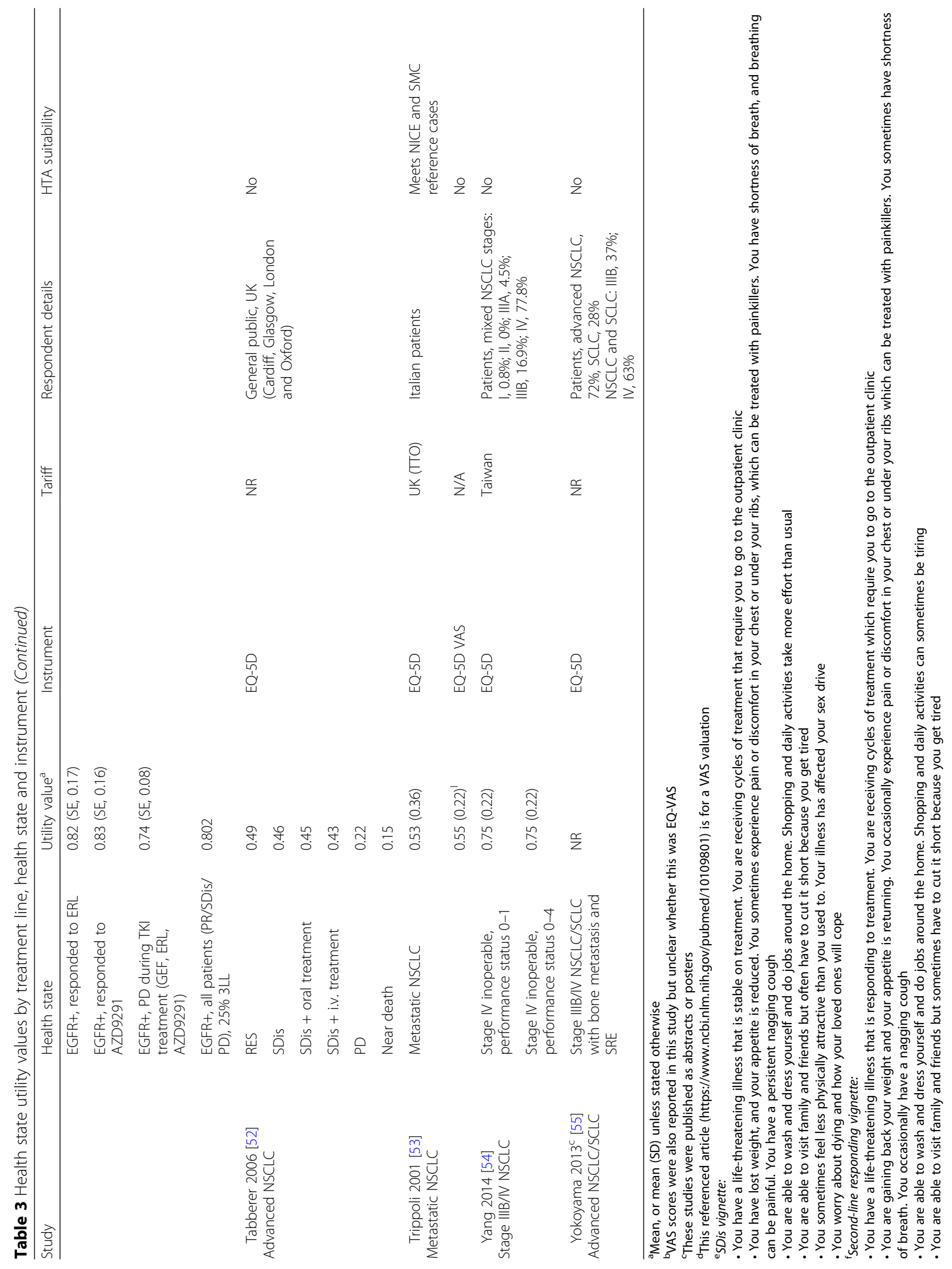




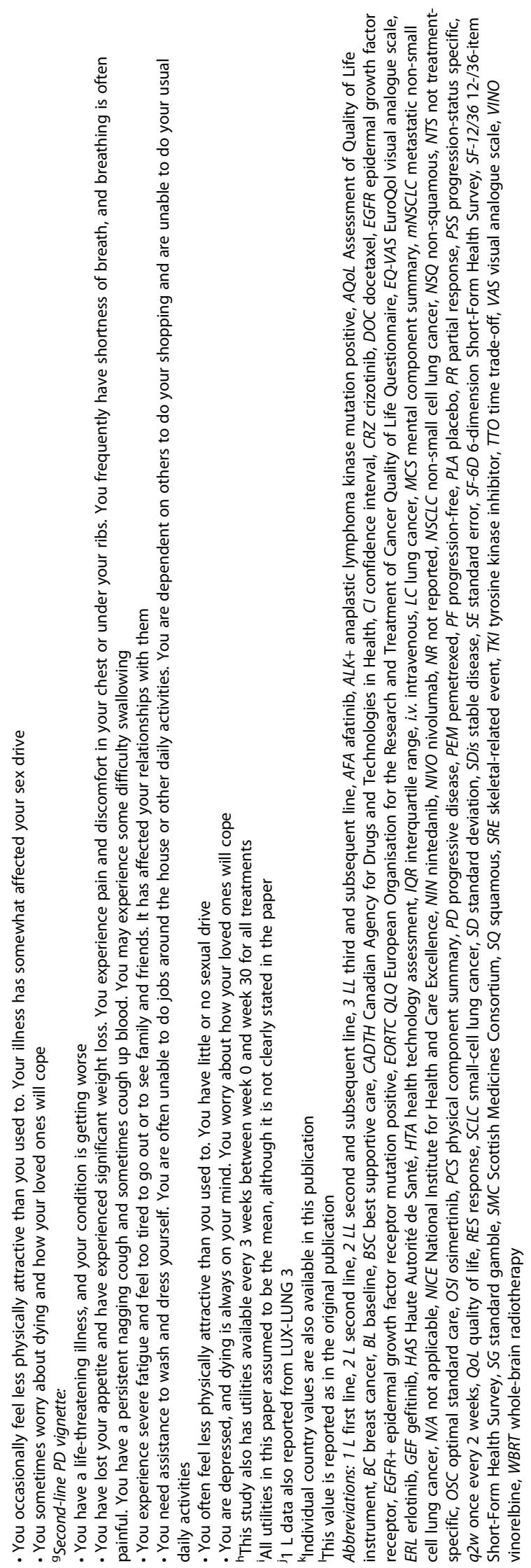




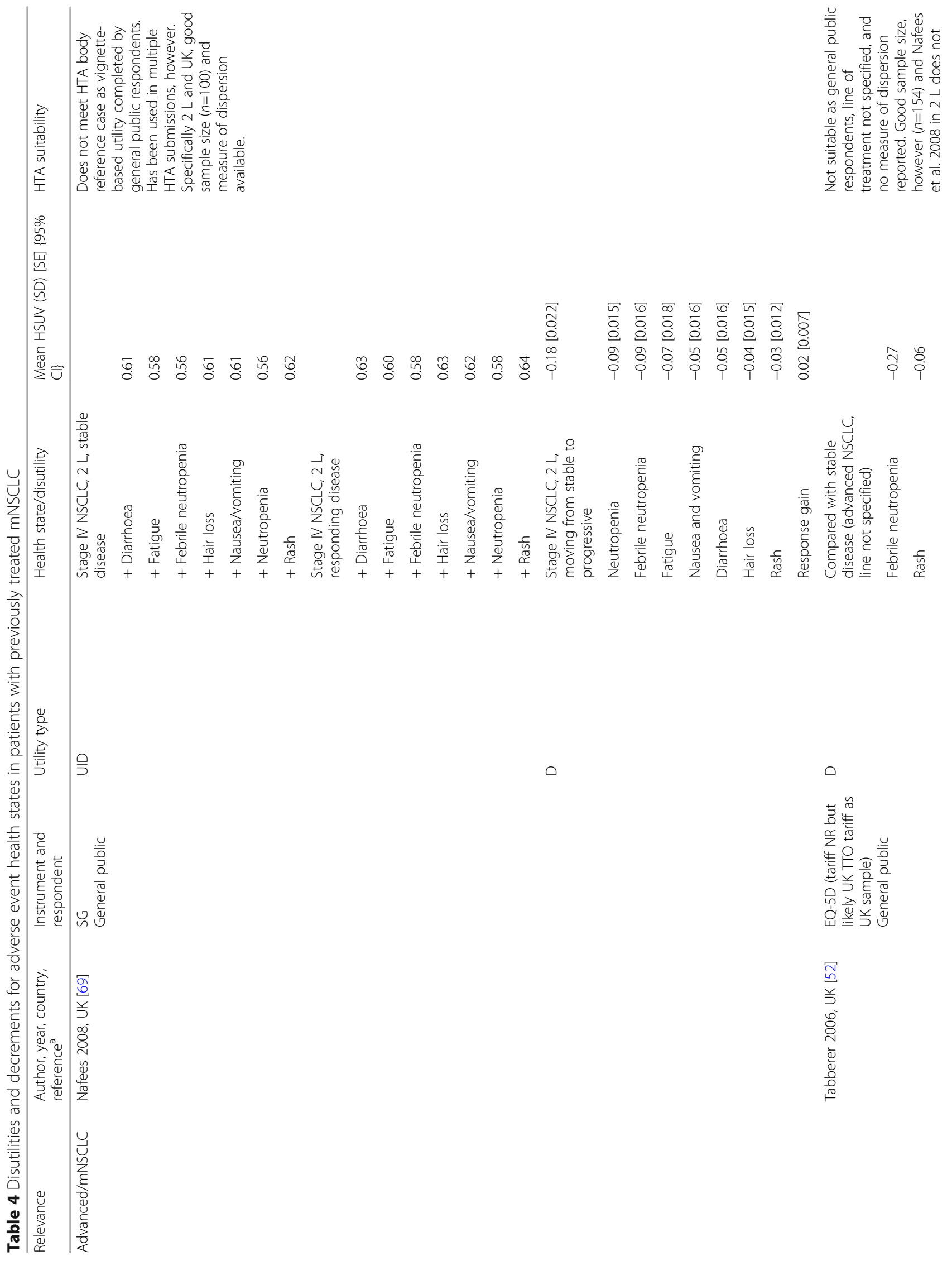




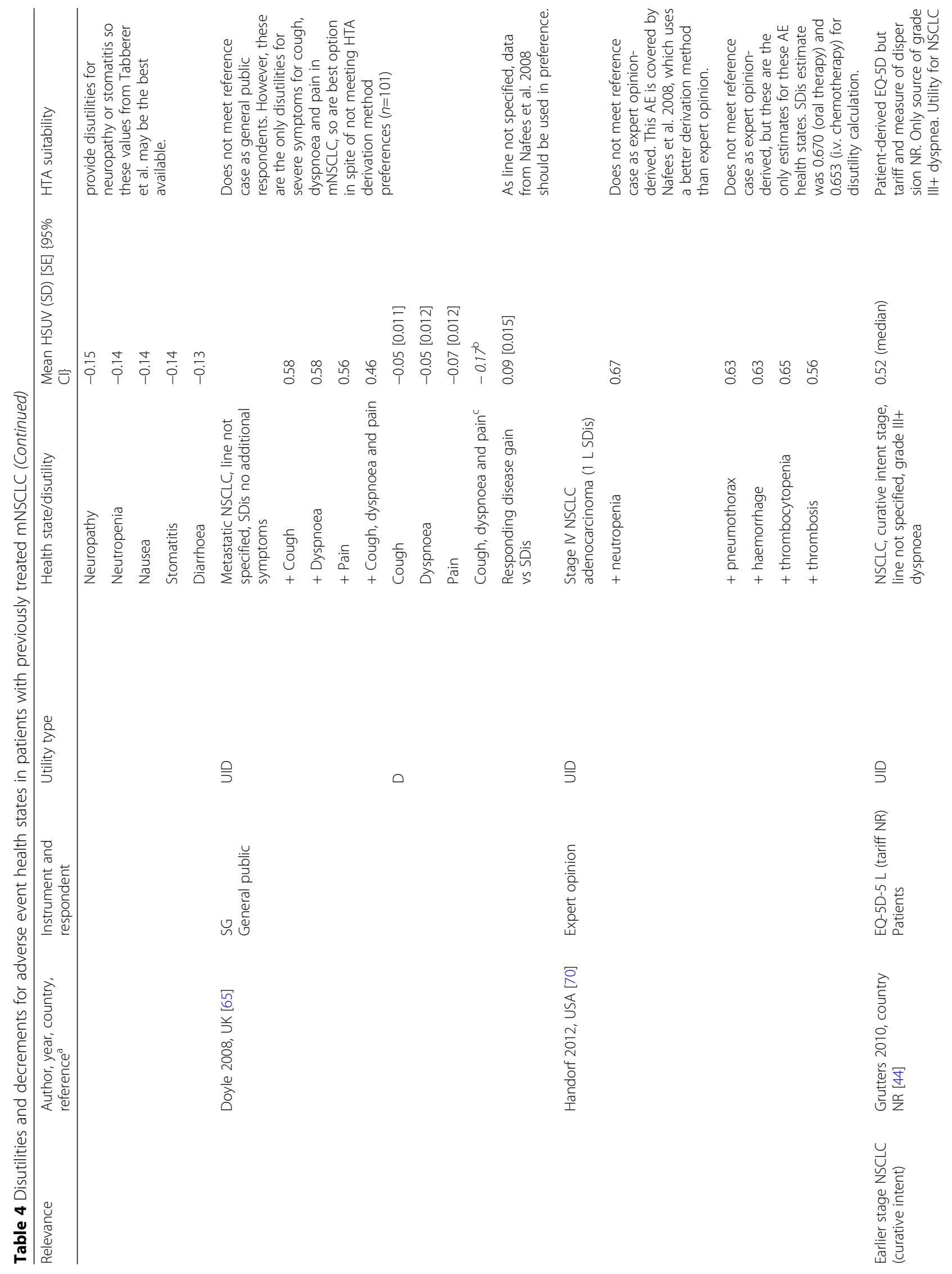




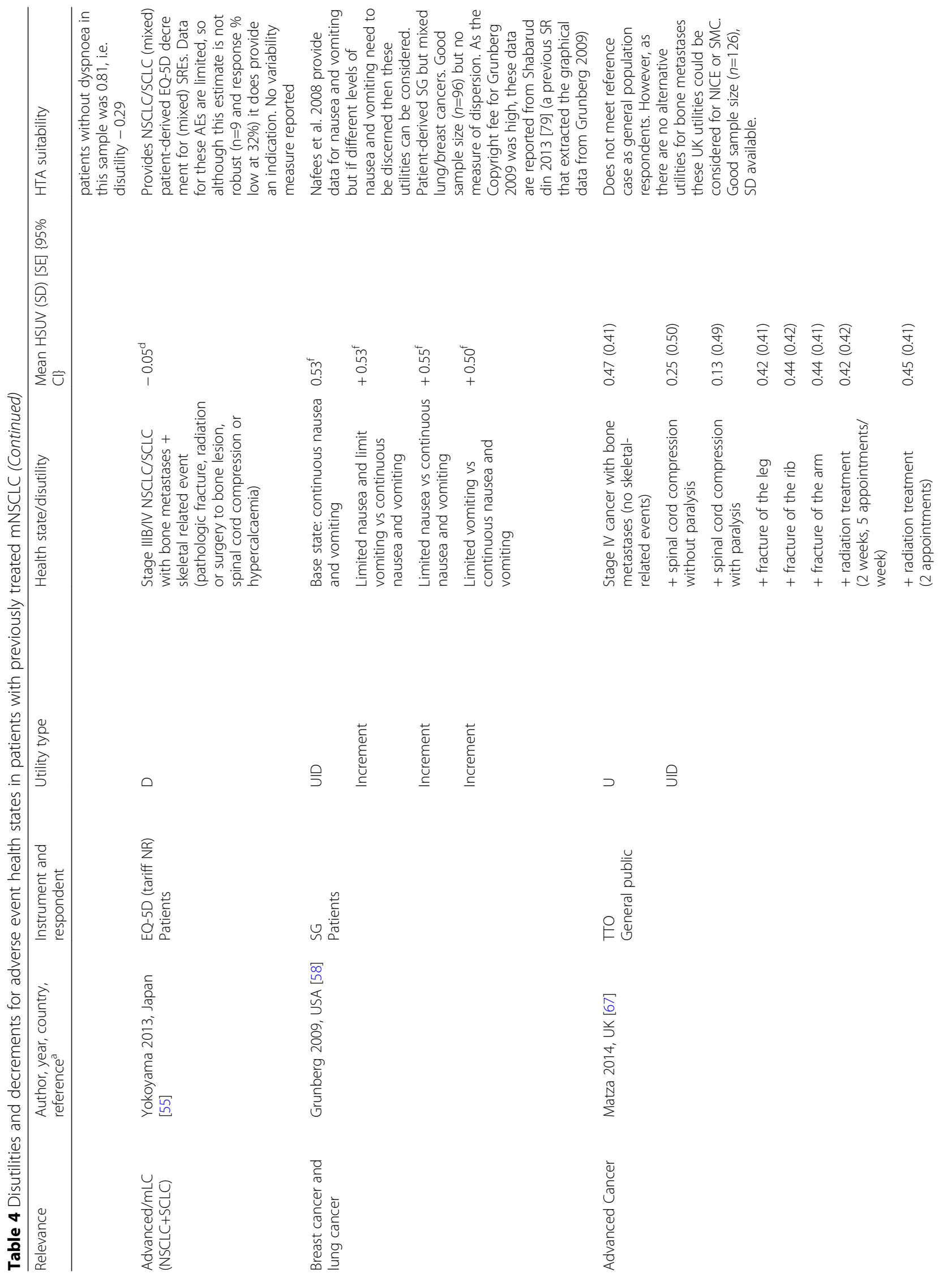




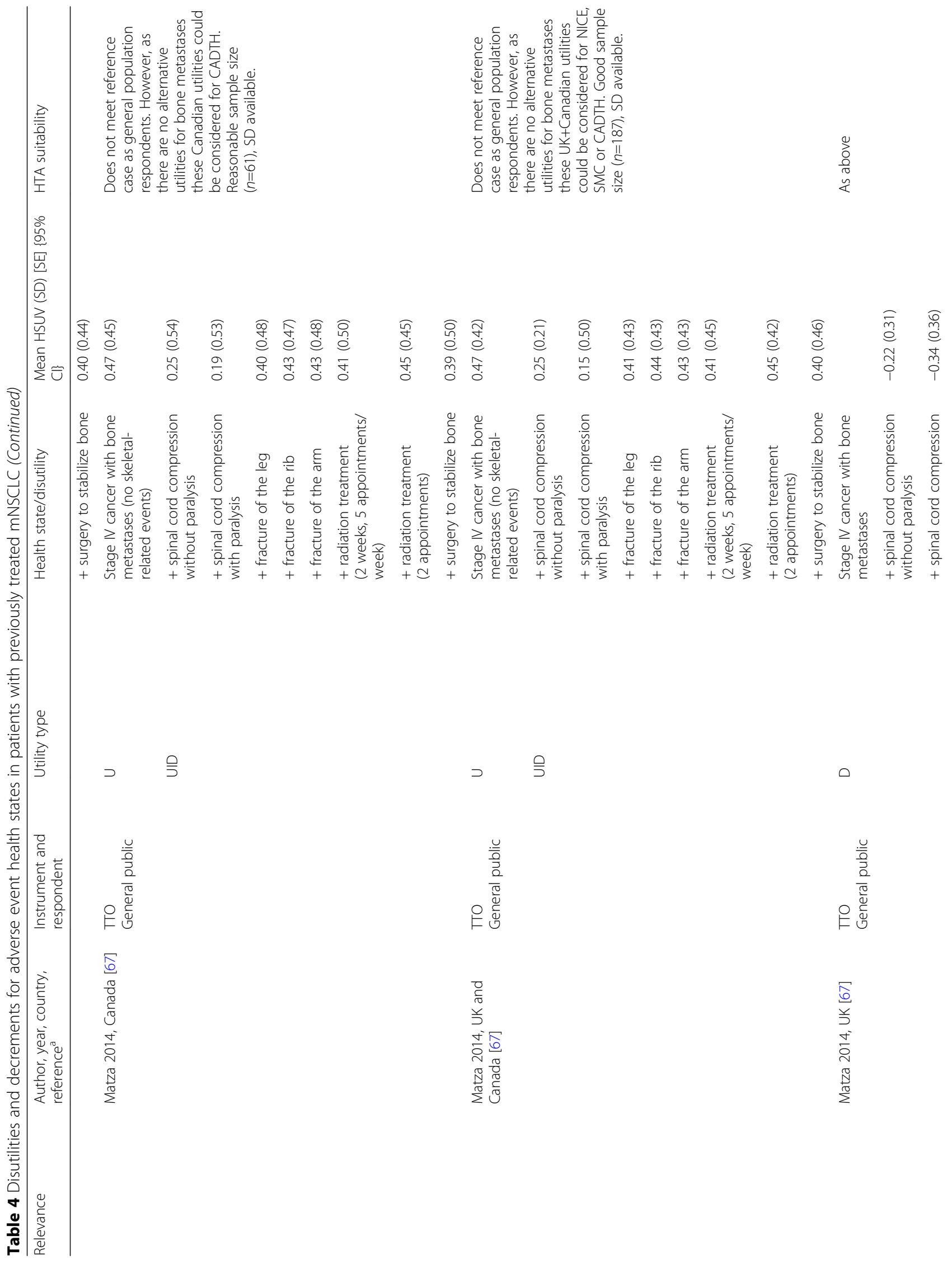




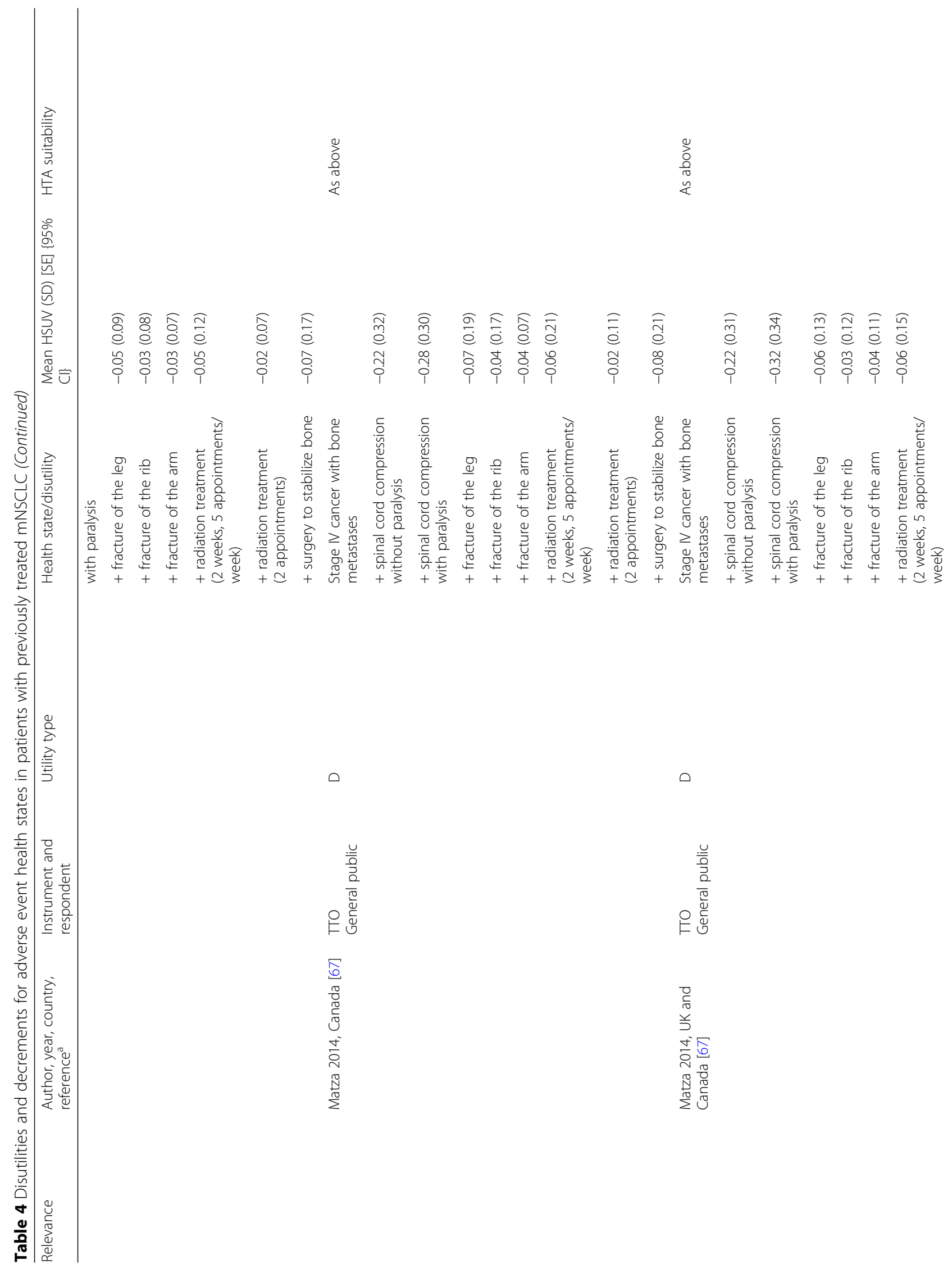




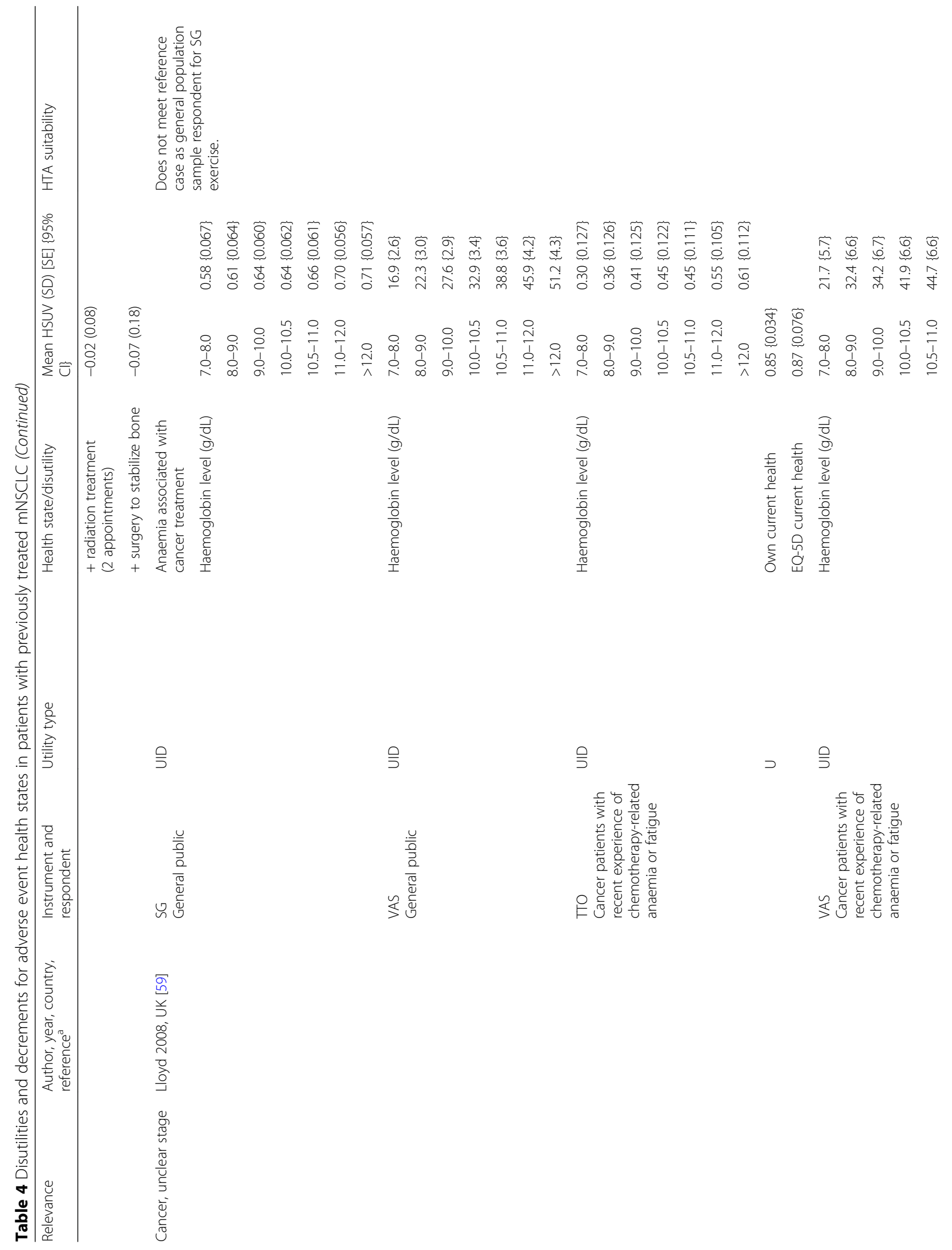




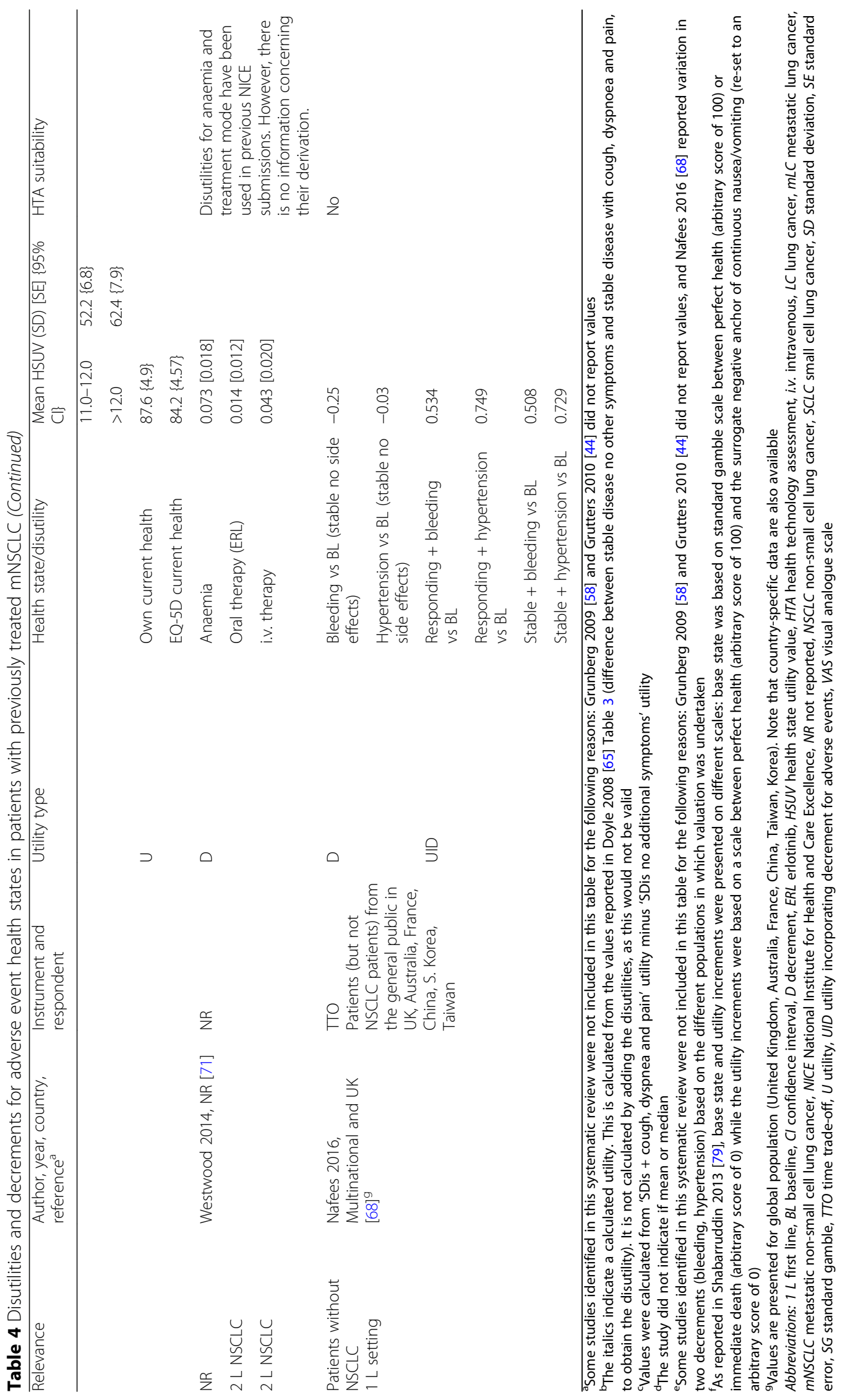


because asking patients suffering such toxicities to complete HRQoL questionnaires was considered to be too burdensome for patients and potentially unethical. Moreover, although the variation may be large, it helps decision makers to identify where variability exists and informs the design of sensitivity analyses.

In the 36 publications identified, 13 provided HSUVs that meet the NICE reference case or are considered acceptable to the HTA agencies of interest $[37-40,42,45,46,49,53,56,58,64,69]$. These were deemed suitable because HRQoL was measured using the EQ-5D [37-40, 42, 45, 46, 49, 53, 56] or SG [58, 64, 69], both measures preferred or accepted by several HTA authorities. This endeavour fills an important gap in the field because hitherto, only two reports had described HSUVs in mNSCLC $[68,69]$; neither was a systematic review of the literature, nor did they assess their appropriateness for use in economic evaluations.

This systematic review did not identify an HSUV report based on data from the OAK trial (NCT02008227), because it was published as a congress abstract after the cut-off date for literature searching [76]. However, the HSUVs are relevant to the aims of this systematic review, and a brief description is provided below for completeness. Patients with locally advanced NSCLC or mNSCLC after failure of platinum-containing chemotherapy were randomized in a phase 3 trial to receive atezolizumab or docetaxel [76, 77]. As part of the trial, patients completed the EQ-5D, and the resultant HSUVs were presented by time point before death. This study is similar to Huang et al. 2016, which also presented time-to-death EQ-5D utilities for a similar patient group receiving immunotherapy, except comparing pembrolizumab and docetaxel [45]. Overall, HSUVs were very similar between studies at approximately equivalent time points. In the OAK study, the following HSUVs were reported by time point before death: 0.77 ( $>210$ days), 0.71 (105210 days), 0.61 (35-105 days) and 0.39 (<35 days). For comparison, HSUVs published by Huang et al. 2016 were 0.73 (180-360 days), 0.69 (90-180 days), 0.60 (30-90 days) and 0.40 (<30 days). A further study evaluating the efficacy of immunotherapy in patients with NSCLC showed that baseline mean EQ-VAS and EQ-5D index scores were similar for nivolumab (63.7 and 0.68 , respectively) and docetaxel (66.3 and 0.66, respectively) [50].

Strengths of this systematic review include the wide range of data sources searched and the search string design, which enabled identification of disutilities and utility decrements for a wide range of AEs and progressive disease states (e.g. common sites of metastasis from lung cancer) of relevance to the experience of patients previously treated for mNSCLC. We have presented
HSUVs by line of treatment, allowing use in economic modelling, and have discussed HSUVs likely to be accepted by the HTA bodies of interest. Inadequate or inconsistent reporting is common, and low sample sizes and response rates considerably impact on the reported confidence intervals of the reported results. However, among the studies identified here, most reported sample size (over 100 respondents in most cases), many provided a measure of variability for the values reported, and several were based on response rates greater than $80 \%$ (although response rates were unreported in more than half of the studies). Moreover, the use of only published HSUVs can be a limitation, as HTA submissions may use HSUVs that have not been previously published. As part of this systematic review, we have therefore searched HTA submissions for any relevant utilities; most HTAs use data reported by Nafees et al. [69]

Limitations of this review include that the label for the upper bound of the utility scale (e.g. "full health" or "perfect health") was not recorded. This has been shown to be a significant predictor of utility in lung cancer [78], so variation in utilities due to a different upper bound label cannot be explored. A further limitation concerns data extraction from some studies presented as congress abstracts or posters. Owing to the word restrictions placed on conference proceedings they may not be considered a robust data source in comparison with full publications. Furthermore, both screening and data extraction were conducted primarily by a single reviewer, and only $50 \%$ of studies were checked by a second reviewer. The exclusion of studies that used mapping to derive EQ-5D and utility values is a further limitation of this study; however, sufficient data obtained through direct measurement were identified to be informative.

\section{Conclusions}

This systematic review begins to address the challenge of identifying reliable estimates of utility values in mNSCLC that are suitable for use in economic evaluations. Our work has also highlighted that these estimates are vulnerable to variations in study type, tariff, health state and the measures used, and that shortcomings in reporting are common.

\section{Additional files}

Additional file 1: Table S1. Search strings. (DOCX $90 \mathrm{~kb}$ )

Additional file 2: Table S2. Listing of first-line $\mathrm{mNSCLC}$ studies with utility data excluded at second pass [80-100]. (DOCX 84 kb)

Additional file 3: Figure S1. Hierarchy of preferred methodology for generation of HSUVs for different HTA agencies. (PDF $1172 \mathrm{~kb}$ )

Additional file 4: Table S3. Quality assessment of identified studies. (DOCX 111 kb) 


\section{Abbreviations}

AE: Adverse event; AQoL: Assessment of Quality of Life instrument; CADTH: Canadian Agency for Drugs and Technologies in Health; HAS: Haute Autorité de Santé; HRQoL: Health-related quality of life; HSUV: Health state utility value; HTA: Health technology assessment; mNSCLC: Metastatic nonsmall cell lung cancer; NICE: National Institute for Health and Care Excellence; NSCLC: Non-small cell lung cancer; PBAC: Australian Pharmaceutical Benefits Advisory Committee; PICOS: Patient, intervention, comparator, outcome, study; PRISMA: Preferred Reporting Items for Systematic Reviews and MetaAnalyses; QALY: Quality-adjusted life-year; RECIST: Response Evaluation Criteria in Solid Tumors; SF-12/SF-36: 12-/36-item Short-Form Health Survey; SF-6D: 6-dimension Short-Form Health Survey; SG: Standard gamble; SMC: Scottish Medicines Consortium; TTO: Time trade-off; VAS: Visual analogue scale

\section{Acknowledgements}

Medical writing support was provided by Christian Eichinger of PharmaGenesis London, London, UK and was funded by Roche.

\section{Availability of data and materials}

Not applicable. The data presented in this systematic review are published and can be found in the cited original references.

\section{Disclosures}

NP is an employee of F. Hoffmann-La Roche. AA was an employee of F. Hoffman-La Roche at the time the study was conducted. KSM is an employee of Epidemica Ltd.

\section{Authors' contributions}

NP, AA and KSM carried out the conception and design, participated in the review and critique process, drafted the manuscript, and revised it critically for intellectual content. The systematic review was carried out by KSM from Epidemica Ltd., UK and was funded by Roche. All authors read and approved the final manuscript.

\section{Ethics approval and consent to participate}

Not applicable.

\section{Consent for publication}

Not applicable.

\section{Competing interests}

The authors declare that they have no competing interests.

\section{Publisher's Note}

Springer Nature remains neutral with regard to jurisdictional claims in published maps and institutional affiliations.

\section{Author details}

${ }^{1}$ F. Hoffmann-La Roche AG, Basel, Switzerland. ${ }^{2}$ Epidemica Ltd, Bicester, Oxfordshire, UK. ${ }^{3}$ Present address: Digipharm, Zug, Switzerland.

\section{Received: 8 February 2018 Accepted: 8 August 2018}

Published online: 12 September 2018

\section{References}

1. Jemal A, Bray F, Center MM, Ferlay J, Ward E, Forman D. Global cancer statistics. CA Cancer J Clin. 2011;61:69-90.

2. American Cancer Society. What is non-small cell lung cancer? Available at https://www.cancer.org/cancer/non-small-cell-lung-cancer/about/what-isnon-small-cell-lung-cancer.html. Accessed 24 Aug 2017.

3. Edge SB, Byrd DR, Compton CC. AJCC cancer staging handbook. 7th ed. New York, NY: Springer; 2010

4. Eisenhauer EA, Therasse P, Bogaerts J, Schwartz LH, Sargent D, Ford R, et al. New response evaluation criteria in solid tumours: revised RECIST guideline (version 1.1). Eur J Cancer. 2009;45:228-47.

5. Tsao AS. Lung carcinoma. Available at http://www.msdmanuals.com/ professional/pulmonary-disorders/tumors-of-the-lungs/lung-carcinoma. Accessed 8 Nov 2017.
6. CancerCare ${ }^{\circledast}$. Types and staging of lung cancer. Available at https://www. lungcancer.org/find_information/publications/163-lung_cancer_101/268types_and_staging. Accessed 24 Aug. 2017.

7. Novello S, Barlesi F, Califano R, Cufer T, Ekman S, Levra MG, et al. Metastatic non-small-cell lung cancer: ESMO clinical practice guidelines for diagnosis, treatment and follow-up. Ann Oncol. 2016;27:1-27.

8. Lemjabbar-Alaoui H, Hassan OU, Yang YW, Buchanan P. Lung cancer: biology and treatment options. Biochim Biophys Acta. 1856;2015:189-210.

9. American Cancer Society. Non-small cell lung cancer survival rates, by stage. Available at https://www.cancer.org/cancer/non-small-cell-lung-cancer/ about/what-is-non-small-cell-lung-cancer.html. Accessed 24 Aug 2017.

10. Camps C, del Pozo N, Blasco A, Blasco P, Sirera R. Importance of quality of life in patients with non-small-cell lung cancer. Clin Lung Cancer. 2009;10:83-90.

11. American Cancer Society. Non-small cell lung cancer signs and symptoms. Available at https://www.cancer.org/cancer/non-small-cell-lung-cancer/ detection-diagnosis-staging/signs-symptoms.html. Accessed 24 Aug 2017.

12. Cella DF, Patel JD. Improving health-related quality of life in non-small-cell lung cancer with current treatment options. Clin Lung Cancer. 2008;9:206-12.

13. Brazier JE, Papaioannou D, Cantrell A. Identifying and reviewing health state utility values for populating decision models. In: Shemilt I, Mugford M, Vale L, Marsh K, Donaldson C, editors. Evidence-based decisions and economics: health care, social welfare, education and criminal justice. 2nd ed. Oxford: Wiley-Blackwell; 2010.

14. Whitehead SJ, Ali S. Health outcomes in economic evaluation: the QALY and utilities. Br Med Bull. 2010;96:5-21.

15. Paracha N, Thuresson PO, Moreno SG, MacGilchrist KS. Health state utility values in locally advanced and metastatic breast cancer by treatment line: a systematic review. Expert Rev Pharmacoecon Outcomes Res. 2016;16:549-59.

16. EQ-5D: EQ-5D-3L user guide. Basic information on how to use the EQ-5D-3L instrument. Version 5.1.2015; Available at https://euroqol.org/wp-content/ uploads/2016/09/EQ-5D-3L_UserGuide_2015.pdf. Accessed 22 May 2018.

17. EQ-5D: EQ-5D-5L user guide. Basic information on how to use the EQ-5D-5L instrument. Version 2.1.2015; Available at https://euroqol.org/wp-content/ uploads/2016/09/EQ-5D-5L_UserGuide_2015.pdf. Accessed 22 May 2018.

18. Torrance GW, Feeny DH, Furlong WJ, Barr RD, Zhang Y, Wang Q. Multiattribute utility function for a comprehensive health status classification system. Health utilities index mark 2. Med Care. 1996;34:702-22.

19. Brazier J, Roberts J, Deverill M. The estimation of a preference-based measure of health from the SF-36. J Health Econ. 2002;21:271-92.

20. Assessment of Quality of Life. What is AQoL? 2014; Available at: https:// www.aqol.com.au/index.php/aqoldevelopment. Accessed 22 May 2018.

21. 15D instrument: Use of 15D. Available from http://15d-instrument.net/useof-the-15d/. Accessed 22 May 2018).

22. Seiber WJ, Grossel EJ, David KM, Ganiats TG, Kaplan RM. Quality of well being Self-Administered (QWB-SA) scale. User's Manual. 2008; Available at https://hoap.ucsd.edu/qwb-info/QWB-Manual.pdf. Accessed 22 May 2018.

23. Brazier JE, Roberts J. The estimation of a preference-based measure of health from the SF-12. Med Care. 2004;42:851-9.

24. National Institute for Health and Care Excellence. Guide to the methods of technology appraisal. 2013; Available at https://www.nice.org.uk/process/ pmg9/chapter/foreword. Accessed 8 Nov 2017.

25. National Institute for Health and Care Excellence. Decision Support Unit. NICE DSU Technical Support Document 11. Alternatives to EQ-5D for generating health state utility values. 2011; Available at http://scharr.dept. shef.ac.uk/nicedsu/wp-content/uploads/sites/7/2016/03/TSD11-Alternativesto-EQ-5D_final.pdf. Accessed 8 Nov 2017].

26. Scottish Medicine Consortium. Guidance to manufacturers for completion of new product assessment form (NPAF). 2014; Available at https://www. scottishmedicines.org.uk/Submission_Process/Submission_guidance_and_ forms/Templates-Guidance-for-Submission. Accessed 8 Nov 2017.

27. Canadian Agency for Drugs and Technologies. Guidelines for the economic evaluation of health technologies: Canada 3rd Edition. 2016; Available at https:/ www.cadth.ca/media/pdf/186_EconomicGuidelines_e.pdf. Accessed 8 Nov. 2017.

28. Haute Autorité de Santé (HAS). Choices in methods for economic evaluation. 2012; Available at https://www.has-sante.fr/portail/upload/docs/ application/pdf/2012-10/choices_in_methods_for_economic_evaluation.pdf. Accessed 8 Nov 2017

29. Pharmaceutical Benefits Advisory Committee. Guidelines for preparing submissions to the Pharmaceutical Benefits Advisory Committee (Version 5.0). 2016; Available at https:/pbac.pbs.gov.au/content/information/files/pbacguidelines-version-5.pdf. Accessed 8 Nov 2017. 
30. Arber M, Garcia S, Veale T, Edwards M, Shaw A, Glanville J. Sensitivity of a search filter designed to identify studies reporting health state utility values. In HTA International Conference, Oslo, Norway. 2015.

31. National Institute for Health and Care Excellence: Position statement on use of the EQ-5D-5L valuation set. 2017; Available at: https://www.nice.org. uk/Media/Default/About/what-we-do/NICE-guidance/NICE-technologyappraisal-guidance/eq5d5I_nice_position_statement.pdf. Accessed 3 of July 2018

32. Moher D, Liberati A, Tetzlaff J, Altman DG. Preferred reporting items for systematic reviews and meta-analyses: the PRISMA statement. Ann Intern Med. 2009:151:264-9.

33. Qatar Computing Research Institute. Rayyan. Available at http://rayyan.qcri. org/. Accessed 20 Nov 2017

34. European Network for Health Technology Assessment. Process of information retrieval for systematic reviews and health technology assessments on clinical effectiveness. 2017; Available at https://www.eunethta. eu/process-of-information-retrieval-for-systematic-reviews-and-healthtechnology-assessments-on-clinical-effectiveness/. Accessed 3 July 2018.

35. Papaioannou D, Brazier J, Paisley S. Systematic searching and selection of health state utility values from the literature. Value Health. 2013;16:686-95.

36. International Society of Pharmacoeconomics and Outcomes Research: Identification, review and use of health state utility data in costeffectiveness models: good practices for outcomes research. 2018. Available from https://www.ispor.org/member-groups/task-forces/health-state-utilityestimates-in-cost-effectiveness-models. Accessed 24 May 2018.

37. Griebsch I, Palmer M, Fayers PM, Ellis S. Is progression-free survival associated with a better health-related quality of life in patients with lung cancer? Evidence from two randomised trials with afatinib. BMJ Open. 2014; 4:e005762

38. Chevalier J, Le Lay K, De Pouvourville G. Health state utility values in advanced non-small cell lung cancer patients. Value Health. 2013;16:A419.

39. Chouaid C, Agulnik J, Goker E, Herder GJM, Lester JF, Vansteenkiste J, et al. Health-related quality of life and utility in patients with advanced nonsmall-cell lung cancer: a prospective cross-sectional patient survey in a realworld setting. J Thorac Oncol. 2013;8:997-1003.

40. Hirsh V, Cadranel J, Cong XJ, Fairclough D, Finnern HW, Lorence RM, et al. Symptom and quality of life benefit of afatinib in advanced non-small-cell lung cancer patients previously treated with erlotinib or gefitinib: results of a randomized phase iib/iii trial (lux-lung 1). J Thorac Oncol. 2013;8:229-37.

41. Blackhall F, Kim DW, Besse B, Nokihara H, Han JY, Wilner KD, et al. Patientreported outcomes and quality of life in PROFILE 1007: a randomized trial of crizotinib compared with chemotherapy in previously treated patients with ALK-positive advanced non-small-cell lung cancer. J Thorac Oncol. 2014;9: 1625-33.

42. Bradbury PA, Jang $R$, Isogai $P, N g$, Mittmann $N$, Evans W, et al. A cost utility analysis of erlotinib in patients with previously treated advanced nonsmall-cell lung cancer (NSCLC). Value Health. 2008;11:A72.

43. Dansk V, Large S, Bertranou E, Bodnar C, Dyer MT, Ryan J. A review of health state utility values used in UK NICE appraisals in advanced NSCLC. Value Health. 2016;19:A745.

44. Grutters J, Joore M, Wiegman E, Langendijk H, De Ruysscher D, Hochstenbag $M$, et al. Health-related quality of life in patients surviving non-small cell lung cancer. Radiother Oncol. 2010:96:S344-5.

45. Huang M, Pellissier J, Liao J. A trial-based EuroQol EQ-5D health utility analysis in patients with previously treated advanced NSCLC. Value Health. 2016;7:PCN198.

46. Iyer S, Taylor-Stokes G, Roughley A. Symptom burden and quality of life in advanced non-small cell lung cancer patients in France and Germany. Lung Cancer. 2013:81:288-93.

47. Jang RW, Isogai PK, Mittmann N, Bradbury PA, Shepherd FA, Feld R, et al. Derivation of utility values from European Organization for Research and Treatment of Cancer Quality of Life-Core 30 questionnaire values in lung cancer. J Thorac Oncol. 2010;5:1953-7

48. Langley RE, Stephens RJ, Nankivell M, Pugh C, Moore B, Navani N, et al. Interim data from the Medical Research Council QUARTZ trial: does whole brain radiotherapy affect the survival and quality of life of patients with brain metastases from non-small cell lung cancer? Clin Oncol (R Coll Radiol). 2015;25:e23-30

49. Novello S, Kaiser R, Mellemgaard A, Douillard JY, Orlov S, Krzakowski M, et al. Analysis of patient-reported outcomes from the LUME-lung 1 trial: a randomised, double-blind, placebo-controlled, phase III study of second-line nintedanib in patients with advanced non-small cell lung cancer. Eur J Cancer. 2015;51:317-26.

50. Reck M, Coon C, Taylor F, DeRosa M, Penrod JR, Dastani H, et al. Evaluation of overall health status in patients with advanced squamous non-small cell lung cancer treated with nivolumab or docetaxel in CheckMate 017. Eur J Cancer. 2015:51:S599-600.

51. Schuette W, Tesch H, Buttner H, Krause T, Soldatenkova V, Stoffregen C. Second-line treatment of stage III/IV non-small-cell lung cancer (NSCLC) with pemetrexed in routine clinical practice: evaluation of performance status and health-related quality of life. BMC Cancer. 2012;12:14.

52. Tabberer M, Stamuli E, Walker M, Summerhayes M, Lees M. Utilities associated with non-small cell lung cancer (NSCLC): a community study. Value Health. 2006:9:A298.

53. Trippoli S, Vaiani M, Lucioni C, Messori A. Quality of life and utility in patients with non-small cell lung cancer. PharmacoEconomics. 2001;19:855-63.

54. Yang SC, Lai WW, Chang HY, Su WC, Chen HHW, Wang JD. Estimation of loss of quality-adjusted life expectancy (QALE) for patients with operable versus inoperable lung cancer: adjusting quality-of-life and lead-time bias for utility of surgery. Lung Cancer. 2014;86:96-101.

55. Yokoyama T, Kunikane H, Katakami N, Yokota I, Saio Y, Shimozuma K, et al. A prospective analysis of the association between skeletal-related events and quality of life in patients with advanced lung cancer (CSP-HOR13). Eur J Cancer. 2013:49:S284.

56. Stewart EL, Labbe C, Brown C, Perez-Cosio A, Vennettilli A, Patel D, Cheng $\mathrm{N}$, Liang $\mathrm{M}, \mathrm{Gill} \mathrm{G}$, Leung $\mathrm{Y}$, et al. Patient-reported health utility scores (HUS) in non-small cell lung cancer (NSCLC) patients with epidermal growth factor receptor (EGFR) mutations by drug therapy. Pharmacoepidemiol Drug Saf. 2015;24:52

57. Rudell K, Papadakis K, Bodnar C, Hoyle C, Ghlorghlu S, Ryden A. The impact of osimertinib on function and health status for patients with EGFR mutation-positive advanced non-small cell lung cancer. J Clin Oncol. 2016; 34:e20548.

58. Grunberg SM, Weeks J, Magnan WF, Herndon J, Naughton ML, Blackwell $\mathrm{KLC}$, et al. Determination of utility scores for control of chemotherapyinduced nausea or vomiting - CALGB 309801. J Support Oncol. 2009;7: W17-22.

59. Lloyd A, van Hanswijck de Jonge P, Doyle S, Cornes P. Health state utility scores for cancer-related anemia through societal and patient valuations. Value Health. 2008;11:1178-85.

60. Schwartzberg L, Chandler J, Reynold C, Garon EB, Stepanski EJ, Keogh GP, et al. Symptom analysis and quality of life (QoL) in patients treated with nivolumab (NIVO) as $\geq 2$ nd line therapy for advanced non-small cell lung cancer (aNSCLC). Eur J Cancer. 2015;51:S628-9.

61. Manser RL, Wright G, Byrnes G, Hart D, Conron M, Carter R, et al. Validity of the assessment of quality of life (AQoL) utility instrument in patients with operable and inoperable lung cancer. Lung Cancer. 2006;53:217-29.

62. Linnet $\mathrm{H}$, Hansen $\mathrm{O}$, Meldgaard $\mathrm{P}$, Berdeaux $\mathrm{G}$, Mercier F. Health related quality of life of caregivers and patients treated for metastatic non-small cell lung cancer (NSCLC) with oral vinorelbine. Value Health. 2015;18:A473.

63. Chang C, Park S, Choi YR, Tan SC, Kang SH, Back HJ, et al. Measurement of utilities by time to death related to advanced non-small cell lung cancer in South Korea. Value Health. 2016;19:A744.

64. Chen W. Cost-effectiveness of epidermal growth factor receptor gene mutation testing for patients with advanced non-small cell lung cancer living in Ontario. Value Health. 2011;14:A82.

65. Doyle S, Lloyd A, Walker M. Health state utility scores in advanced non-small cell lung cancer. Lung Cancer. 2008;62:374-80.

66. Lloyd AJ, Van Hanswijck De Jonge P, Doyle S, Walker M, Farina C. Development and elicitation of health state utilities in metastatic non small cell lung cancer (NSCLC) in the UK. 27th North American Meeting of the Society for Medical Decision Making. 2005; Available at https:// smdm.confex.com/smdm/2005ca/techprogram/P2165.HTM. Accessed 20 Nov. 2017.

67. Matza LS, Chung K, Van Brunt K, Brazier JE, Braun A, Currie B, et al. Health state utilities for skeletal-related events secondary to bone metastases. Eur J Health Econ. 2014;15:7-18.

68. Nafees B, Lloyd AJ, Dewilde S, Rajan N, Lorenzo M. Health state utilities in non-small cell lung cancer: an international study. Asia Pac J Clin Oncol. 2017;13:e195-203.

69. Nafees B, Stafford M, Gavriel S, Bhalla S, Watkins J. Health state utilities for non small cell lung cancer. Health Qual Life Outcomes. 2008;6:84. 
70. Handorf EA, McElligott S, Vachani A, Langer CJ, Demeter MB, Armstrong K, et al. Cost effectiveness of personalized therapy for first-line treatment of stage IV and recurrent incurable adenocarcinoma of the lung. J Oncology Pract. 2012:8:267-74

71. Westwood M, Joore M, Whiting P, van Asselt T, Ramaekers B, Armstrong N, et al. Epidermal growth factor receptor tyrosine kinase (EGFR-TK) mutation testing in adults with locally advanced or metastatic non-small cell lung cancer: a systematic review and cost-effectiveness analysis. Health Technol Assess. 2014;18:1-165.

72. Vargas J, Gomez Rangel JD, Martínez-Barrera L, Mendoza D, Paladio Á. Evaluation of the quality of life in patients with non-small cell lung cancer who failed to first line chemotherapy in treatment with erlotinib vs taxanes. Value Health. 2009;12:A284.

73. Chen E, Buerki C, Saad F, Laouri M. Initial evaluation of the health economic impact of a prognostic 15-gene expression-based signature in early-stage NSCLC patient management. J Thorac Oncol. 2010;5:S241.

74. Ara R: Synthesising heath state utility values. Presented at the International Society of Pharmacoeconomics Outcomes Research 20th Annual European Congress, 4-8 November 2017, Glasgow, UK.

75. Petrou S, Kwon J, Madan J. A practical guide to conducting a systematic review and meta-analysis of health state utility values. Pharmacoeconomics. 2018. https://doi.org/10.1007/s40273-018-0670-1.

76. Purchase JP, Paracha N, Abdulla A. Health-related quality of life in cancer immunotherapy: second line non-small-cell lung cancer. Value Health. 2017; 20:A450.

77. Rittmeyer A, Barlesi F, Waterkamp D, Park K, Ciardiello F, von Pawel J, et al. Atezolizumab versus docetaxel in patients with previously treated nonsmall-cell lung cancer (OAK): a phase 3, open-label, multicentre randomised controlled trial. Lancet. 2017;389:255-65.

78. Sturza J. A review and meta-analysis of utility values for lung cancer. Med Decis Mak. 2010;30:685-93.

79. Shabaruddin FH, Chen L-C, Elliott RA, Payne K. A systematic review of utility values for chemotherapy-related adverse events. PharmacoEconomics. 2013; 31:277-88.

80. Balçik $Y$, Şahin B. Cost-effectiveness analysis of pemetrexed and gemcitabine treatment for advanced nonsmall cell lung cancer in Turkey. Turk J Med Sci. 2016;46:152-8

81. Barney BJ, Wang XS, Lu C, Liao Z, Johnson VE, Cleeland CS, et al. Prognostic value of patient-reported symptom interference in patients with late-stage lung cancer. Qual Life Res. 2013;22:2143-50.

82. Belani CP, Pereira JR, Pawel J, Pluzanska A, Gorbounova V, Kaukel E, et al. Effect of chemotherapy for advanced non-small cell lung cancer on patients' quality of life. A randomized controlled trial. Lung Cancer. 2006;53: 231-9.

83. Billingham L, Gaunt P, Jarrett H, Dunlop D, Thompson J, O'Byrne KJ, et al. Quality of life in advanced non-small cell lung cancer, effects of cisplatin dose and carboplatin in combination with gemcitabine: results from BTOG2, a British thoracic oncology group phase III trial in 1363 patients. J Thorac Oncol. 2011;6:S319-20.

84. Chouaid C, Bischoff H, Vergnenegre A, Heigener D, Taylor- Stokes G, Roughley A, et al. Real life outcomes and health-related quality of life (HRQOL) in 1st line non-squamous non-small cell lung cancer (NSCLC): a European pilot study analysing bevacizumab-based versus nonbevacizumab-based treatments. J Thorac Oncol. 2011a;6:S1284-5.

85. Chouaid C, Bischoff HG, Vergnenegre A, Heigener DF, Taylor-Stokes G, Roughley $A$, et al. Health-related quality of life (HRQOL) in 1st line nonsquamous non-small cell lung cancer (NSCLC) patients in a real life setting: bevacizumab-based versus non-bevacizumab based therapy in a European pilot study. Value Health. 2011;14:A171.

86. Dranitsaris G, Cottrell W, Evans WK. Cost-effectiveness of chemotherapy for non small-cell lung cancer. Curr Opin Oncol. 2002;14:375-83.

87. Felip E, Blackhall FH, Mok T, Cappuzzo F, Wilner KD, Reisman A, et al. Impact of crizotinib on patient-reported general health status compared with chemotherapy in patients with no prior systemic treatment for advanced non-squamous ALK-positive non-small cell lung cancer (NSCLC). J Clin Oncol. 2015;33:8101.

88. Fleeman N, Bagust A, McLeod C, Greenhalgh J, Boland A, Dundar Y, et al. Pemetrexed for the first-line treatment of locally advanced or metastatic non-small cell lung cancer. Health Technol Assessment. 2010;14:47-53.

89. Galetta D, Cinieri S, Pisconti S, Gebbia V, Morabito A, Borsellino N, et al. Cisplatin/pemetrexed followed by maintenance pemetrexed versus carboplatin/paclitaxel/bevacizumab followed by maintenance bevacizumab in advanced nonsquamous lung cancer: the GOIM (Gruppo Oncologico Italia Meridionale) ERACLE phase III randomized trial. Clin Lung Cancer. 2015:16:262-73.

90. Galetta D, Pisconti S, Cinieri S, Gebbia V, Morabito A, Borsellino N, et al. Firstline pemetrexed plus cisplatin followed by maintenance pemetrexed vs carboplatin-paclitaxel plus bevacizumab followed by maintenance bevacizumab (ERACLE) in advanced non squamous non-small cell lung cancer: a quality of life-oriented, multicenter randomized phase III tria of the GOIM (Gruppo Oncologico Italia Meridionale). J Thorac Oncol. 2013:8:S1002

91. Gridelli C, De Marinis F, Pujol JL, Reck M, Ramlau R, Parente B, et al. Safety, resource use, and quality of life in paramount: a phase III study of maintenance pemetrexed versus placebo after induction pemetrexed plus cisplatin for advanced nonsquamous non-small-cell lung cancer. J Thorac Oncol. 2012;7:1713-21.

92. Hirsh V, Yang JCH, Tan EH, O'Byrne K, Zhang L, Boyer MJ, et al. First-line afatinib (a) vs gefitinib (G) for patients (pts) with EGFR mutation positive (EGFRm+) NSCLC (LUX-lung 7): patient-reported outcomes (PROs) and impact of dose modifications on efficacy and adverse events (AEs). J Clin Oncol. 2016;34:S9046.

93. Khan I, Morris S, Hackshaw A, Lee SM. Cost-effectiveness of first-line erlotinib in patients with advanced non-small-cell lung cancer unsuitable for chemotherapy. BMJ Open. 2015;5:e006733.

94. Lal R, Hillerdal GN, Shah RNH, Crosse B, Thompson J, Nicolson M, et al. Feasibility of home delivery of pemetrexed in patients with advanced nonsquamous non-small cell lung cancer. Lung Cancer. 2015;89:154-60.

95. Langer CJ, Hirsh V, Amiri K, Ko A, Knoble JL, Johnson ML, et al. Quality of life $(\mathrm{QoL})$ by response: an interim analysis of patients (pts) with squamous (SCC) NSCLC treated with nab-paclitaxel/carboplatin (nab-P/C) induction therapy in the phase III ABOUND.sqm study. J Clin Oncol. 2016;34:S64.

96. Langer CJ, Hirsh V, Okamoto I, Lin FJ, Wan Y, Whiting S, et al. Survival, quality-adjusted survival, and other clinical end points in older advanced non-small-cell lung cancer patients treated with albumin-bound paclitaxel. Br J Cancer. 2015;113:20-9.

97. Reck M, Socinski MA, Luft A, Szczesna A, Dediu M, Ramlau R, et al. The effect of necitumumab in combination with gemcitabine plus cisplatin on tolerability and on quality of life: results from the phase 3 SQUIRE trial. J Thorac Oncol. 2016;11:808-18.

98. Shallwani SM, Simmonds MJ, Kasymjanova G, Spahija J. Quality of life, symptom status and physical performance in patients with advanced nonsmall cell lung cancer undergoing chemotherapy: an exploratory analysis of secondary data. Lung Cancer. 2016;99:69-75.

99. Tongpak $\mathrm{P}$, Thongprasert S, Permsuwan U. Utility of advanced non-small cell lung cancer patients in Thailand: preliminary study. Value Health. 2012; 15:A657.

100. Yalçin Balçik P, Şahin B. Cost-effectiveness analysis of pemetrexed and gemcitabine treatment for advanced nonsmall cell lung cancer in Turkey. Turk J Med Sci. 2016;46:152-8.

Ready to submit your research? Choose BMC and benefit from:

- fast, convenient online submission

- thorough peer review by experienced researchers in your field

- rapid publication on acceptance

- support for research data, including large and complex data types

- gold Open Access which fosters wider collaboration and increased citations

- maximum visibility for your research: over $100 \mathrm{M}$ website views per year

At $\mathrm{BMC}$, research is always in progress.

Learn more biomedcentral.com/submissions 